\title{
EMPLOYEE AUTONOMY AND ENGAGEMENT IN THE DIGITAL AGE: THE MODERATING ROLE OF REMOTE WORKING
}

\author{
Aleksandra Boskovic* \\ Faculty of Economics, University of Kragujevac, Kragujevac, the Republic of Serbia
}

In the digitalization era, traditional organizational success factors have been called into question, so it is necessary to reconsider the established work patterns and find new ways to create sustainable value. Given the fact that, as bearers of knowledge, people are the key drivers of value, it is important to explore possible ways to improve their potential. The research study carried out in this paper is aimed showing that autonomy contributes to the development of employee engagement in the digital environment, especially so in remote working conditions. In that sense, the concept of employee engagement was explained, as a state of high vigor, dedication and absorption. Possible ways to improve engagement through increasing autonomy are pointed out as well. The empirical research has confirmed that autonomy has a positive effect on vigor and dedication as the engagement dimensions. The impact autonomy exerts on vigor is stronger in the employees working remotely in comparison with those who do not work remotely.

Keywords: autonomy, job design, employee engagement, remote working, digital environment, organizational design

JEL Classification: M20, M12, J28

\section{INTRODUCTION}

The psychological relationship employees establish with their jobs is a research field gaining in importance in the knowledge economy in the time of accelerated technological progress, when human capital is becoming an increasingly important driver of competitiveness. The development of the

* Correspondence to: A. Boskovic, Faculty of Economics, University of Kragujevac, Liceja Kneževine Srbije 3, 34000 Kragujevac, the Republic of Serbia; e-mail: aboskovic@kg.ac.rs sophisticated skills that lead to superior performance depends on a combination of complex organizational, intellectual, psychological, sociological and other factors.

In the era of knowledge, innovation and technological progress, a company's competitive advantage depends on the generation and implementation of new ideas, as well as the application of new technologies (Simić, Slavković \& Ognjanović, 2020; Savović, Zlatanović \& Nikolić, 2021). Since people are the key bearers of knowledge and capacity for innovation, modern 
organizations require high commitment, investment and energy from employees in order for them to create sustainable value in a highly dynamic environment. Frequent changes and strong pressures on people to quickly adapt to them performing increasingly complex and cognitively demanding tasks can lead to opposite effects. According to Job Demands-Resources Theory, demands can be perceived as challenges or obstacles which will imply a positive or a negative response from employees. Negative reactions are associated with overload, stress and burnout, whereas positive reactions are expected in the case when employees develop high engagement, i.e. vigor, dedication and absorption (Bakker \& Demerouti, 2007).

Numerous factors form the circumstances in which employees' reactions will be shaped. One of the most important antecedents of engagement, however, is the organizational context, especially the way in which a job is designed. Previous research indicates an extremely important role of the workplace autonomy (Kahn, 1990; Saks, 2006; Christian, Garza \& Slaughter, 2011; Shantz, Alfes, Truss \& Soane, 2013; Radošević, Jelić, Matanović and Popov, 2018). Autonomy arises from a greater degree of decentralization, so it is inherent in modern structures, which are flatter, i.e. which have a smaller number of hierarchical levels. Such structures favor the development of innovation and the entrepreneurial capacity in the company (Erić Nielsen, Babić, Stojanović-Aleksić \& Nikolić, 2019; Erić Nielsen, 2020). Freedom encourages creativity and makes it easier to adapt to change. In this context, new leadership models have been developed that support the idea that, under certain conditions, a part of power should be transferred to followers themselves, so that they and the entire organization can achieve an above-average performance (Stojanović-Aleksić, 2016).

This is especially significant in the digital age characterized by exponential changes not only in the development of technology, but also in the economy and society. Previous research has not sufficiently empirically examined the role of autonomy in such a specific context. Although the theory points to the benefits of autonomy both in terms of meeting certain psychological needs and the general wellbeing of an individual, the digital environment is rarely considered as a context for examining the autonomy-engagement relationship. In conditions where the relationship between people and machines has become almost as important as interpersonal relationships, it is necessary to reconsider the traditional mechanisms of encouraging engagement and look for the new ways or mediating factors that can contribute to building long-term and sustainable employee engagement, which will contribute to their personal satisfaction, feeling better at work and in life, and also increase the company's productivity and innovation (Halbesleben, 2010; Christian et al, 2011; Kwon \& Kim, 2020).

Having in mind the importance of the problem area, the subject of the research done in the paper implies the relationship between the workplace autonomy and employee engagement in the digital environment. In this paper, the digital environment means the business environment in which ICT is intensively used in performing tasks. Accordingly, the main research goal is to determine whether and in what way autonomy affects employee engagement in the information technology (IT) sector, which is an example of an industry with pronounced digitalization.

Regarding autonomy, it is important to consider one of the relatively recent trends in organizational design which stands out in the digital environment and relates to remote working. Modern technology has enabled, and newer forms of organizational design have supported, the implementation of the idea that the physical location of work is not always important and that some work can be done outside the office at a location chosen by an employee (e.g. from home, the library, a park, a cafeteria). Recently, this trend has been developing even faster due to the Covid-19 pandemic, because of which some governments have even introduced an obligation for companies to enable their employees to work remotely, specifically from home (Pattnaik \& Jena, 2020). This feature is certainly easier to apply to the jobs done on a computer and not highly dependent on the location/personal contact as is the case, among other jobs, in the IT sector. Although 
remote working has its drawbacks related to isolation and reduced social interactions, research indicates the dominance of positive implications. The following can be mentioned amongst the most significant benefits of teleworking: lower costs (Thomson, 2008), a more pleasant environment in which an employee is more easily committed to performing complex tasks (Golden \& Gajendran, 2019), greater satisfaction and responsible behavior, which leads to greater engagement (Anderson \& Kelliher, 2009). The main advantage of working remotely should be a greater freedom of choice in terms of the place, time and manner of performing tasks. If autonomy is not provided to employees when they work remotely, the positive implications of this concept may not manifest themselves. Therefore, the specific research goal is to determine the moderating influence of remote working in the relationship between autonomy and employee engagement.

Both qualitative and quantitative methodologies are applied in the paper. According to the complex, dynamic and ambiguous nature of the considered phenomena, systemic thinking provides the base. The methods of analysis and synthesis, abstraction and concretization, as well as induction and deduction, are applied. When speaking about the quantitative methodology, the statistical method is used. The data were collected by conducting a survey and analyzed by various statistical techniques.

In addition to the introduction and the conclusion, the paper consists of the literature review, based on which the research hypotheses were developed, and an empirical research study, which served to test the hypotheses. Within the literature review, the essence of the engagement concept is clarified and the key factors influencing the development of employee engagement in modern companies are highlighted. Then, the role of job design as an engagement factor is elaborated and autonomy, as the key characteristic of job design whose effects on engagement are most pronounced in the digital business environment as well. The possible moderating effects of remote working are pointed out as the special circumstances in which the positive effects of autonomy on engagement increase. The research methodology is explained, and the results are presented and discussed.

\section{REFERENCES AND HYPOTHESES DEVELOPMENT}

\section{The concept of employee engagement}

Engagement is a relatively new concept in the scientific literature. However, it has been known in managerial practice for decades. The most successful consulting companies all around the world set the improvement of employee engagement as one of the key goals, as a factor that increases profitability through increased productivity and employee and customer satisfaction (Schaufeli \& Bakker, 2010). Research has later shown that engagement has a number of positive implications, both at individual and at organizational levels. From the positive psychology perspective, work engagement contributes to the individual's need to lead a life fulfilled in every possible aspect (Youssef-Morgan \& Bockorny, 2014). Therefore, the employees who develop a high degree of engagement can be expected to be more satisfied. There are even certain indicators of better physical and mental health in highly engaged workers (Johns, 2012; Shuck, Ghosh, Zigarmi \& Nimon, 2012). Engaged employees are generally more productive, and show higher creativity and proactivity. The organizations that manage to develop high employee engagement can also expect better financial results in the long run (Macey, Schneider, Barbera \& Young, 2009). It is exactly this dual dimension which benefits from engagement (both for individuals and for the organization itself) that is believed to be making this phenomenon so significant.

The concept has received attention in the literature since W. Kahn $(1990,700)$ defined engagement as "the harnessing of organisation members' selves to their work roles; in engagement, people employ and express themselves physically, cognitively, and emotionally during role performances". The author sees engagement as the complete involvement of 
oneself physically, cognitively and emotionally in a job or work role. People establish a kind of symbiotic relationship with their job and it makes them happy.

There is a relatively high degree of agreement in the literature that engagement is a unique and distinctive motivational concept that can be described through the following three dimensions (Salanova, Agut \& Peiró, 2005): vigor, dedication and absorption. Vigor refers to a high level of energy and willingness to put effort into work, regardless of potential difficulties. Dedication indicates high work inspiration, enthusiasm and a sense of pride for the tasks performed. Absorption implies complete immersion in work tasks and activities, as well as the difficulty that a person has to stop working.

The main specificity of the engagement concept, especially as a kind of a company's success indicator, is that it cannot be ordered and is very difficult to be directly controlled. It is created through building long-term relationships and the development of a pleasant working environment. Ever since the concept appeared until today, researchers have tried to determine all the relevant antecedents of engagement in order to find the most concrete and the most detailed answers to the question of how to build an engaged workforce. The literature review has identified certain engagement factors which can be classified into the two broad categories: individual and organizational factors.

Individual factors refer to the different concepts related to an individual's personality, such as personal resources and the personality characteristics. According to job demands-resources theory, the personal resources that stand out as the key engagement factors $\check{z}$ are as follows: self-efficiency, i.e. a personal belief in one's own ability to effectively respond to the demands of different situations, and optimism, which reflects a person's view of the world or the belief that things will go in the desired direction, which increases their enthusiasm and desire to invest themselves in the work role (Crawford, Rich, Buckman \& Bergeron, 2014). In addition to personal resources, there are certain personal characteristics that affect engagement, although the evidence for this assumption is not firmly theoretically grounded, nor is it empirically proven. Certain studies have shown that the characteristics including conscientiousness, proactivity and positive affect are positively correlated with engagement (Saks \& Gruman, 2014). Also, some empirical data suggest that openness and extroversion are the most significant engagement factors among the characteristics that make up the Big Five group (Wollard \& Shuck, 2011). Bearing in mind the importance of personal characteristics as a factor of organizational behavior, as well as the behavior and life of people in general, there is a great lack of research in these issues in the literature.

The organizational factors of employee engagement can be found at the level of work, a group/team and the organization as a whole. The following are amongst the most important: job characteristics, leadership, organizational justice and organizational support. Job characteristics are considered to be the most significant factors influencing employee engagement. Although all job characteristics can affect engagement the following can be highlighted based on the results obtained in the existing empirical research: autonomy, job complexity, problem solving, task variety, feedback from others, person-job harmony, development opportunities, social support (Crawford, LePine \& Rich, 2010; Christian et al, 2011).

\section{The importance of job design for engagement development}

Job design is a system that organizes the performance of a particular job (Sinha \& Van de Ven, 2005, 390). There are many properties that can describe a job, but one of the most comprehensive classifications singles out the three basic dimensions (Morgeson \& Humphry, 2006), namely the task dimension, which describes the structure of the tasks that make up a job (the structural dimension); the knowledge dimension, which contains the characteristics that knowledge requires to perform tasks (the cognitive dimension) and the dimension that describes social interactions at work (the social dimension). The structural dimension includes the following characteristics: the autonomy, variety, significance and identity of tasks, as well as 
job feedback. The cognitive dimension includes job complexity, information processing, problem solving, skill variety and specialization. The social dimension refers to social support, work interdependence, interactions and feedback (Morgeson \& Humphry, 2006). In addition to the three basic work dimensions, job design also includes the context dimension (ergonomics, physical working conditions, etc.), as well as the characteristics of workers themselves. In this paper, the focus is on the aforementioned three basic work dimensions.

The initial, theoretical-methodological basis for considering the relationship between job design and employee engagement is set by Job Demands - Resources Theory, which starts from the question why some people are exhausted from work while others feel enthusiastic and energetic at work. It seeks an answer to this question in the concept of job design. The theory is an extension of the job demands-resources model set by E. Demerouti, A. B. Bakker, F. Nachreiner and W. B. Schaufeli (2001) and further developed by A. B. Bakker and E. Demerouti (2007). The researchers identified the limitations of the existing employee well-being and workplace stress models (the demandcontrol model and the investment and reward balance model) that were too simplistic and static because they dealt with a limited number of variables and did not apply to all people or activities. To overcome the perceived limitations, the job demands-resources model encompassed a wide range of variables. It is based on the assumption that each occupation could have specific risk factors associated with stress at work and engagement, and these factors can be divided into the two general groups called demands and resources.

Job demands are "...those physical, psychological, social, or organizational aspects of the job that require sustained physical and/or psychological (cognitive and emotional) effort or skills and are therefore associated with certain physiological and/ or psychological costs ... (e.g. work pressure, an unfavorable physical environment, and emotionally demanding interactions with clients)" (Bakker \& Demerouti, 2007, 312). Although demands do not necessarily have to be negative, they always require an additional effort to be made. Sometimes, if an employee is unable to respond to a demand, it may lead to negative consequences, such as stress, burnout and health problems. Demands can be classified into challenges (e.g. work responsibilities, deadlines, workload) or hindrances (e.g. an emotional/affective conflict, the organizational policy) (Crawford et al, 2010). Therefore, the relationship between job demands and engagement depends on the type of demands, so challenges are positively associated with engagement, and hindrances are negatively associated with engagement.

Job resources are defined as "those physical, psychological, social, or organizational aspects of the job that are either/or: functional in achieving work goals; reduce job demands and the associated physiological and psychological costs; stimulate personal growth, learning, and development" (Bakker \& Demerouti, 2007, 312). Resources are not exclusively focused on dealing with demands, but also have a motivational role. Internal motivational factors come from the resources that encourage employee personal growth, whereas external motivators come from the resources that are the key instruments for achieving work goals. Job resources can be found at the organizational level, in interpersonal and social relationships and at the job design level as well. Some examples of work-level resources are autonomy, creative tasks, support from superiors and colleagues.

According to Job Demands-Resources theory, stress and burnout will occur when demands are high and available resources are low. However, resources can mitigate the negative effects of a demand (Bakker, Demerouti, Taris, Schaufeli \& Schreurs, 2003) and encourage motivation and engagement.

\section{Autonomy as a factor of employee engagement in the IT sector}

Autonomy can be understood as "the freedom an individual has in carrying out work" (Humphrey, Nahrgang \& Morgeson, 2007, 1333) or as the extent to which work allows for the individual's freedom, independence and discretion with regard to the 
choice of work order, working methods and decisionmaking (Morgeson \& Humphrey, 2006). Autonomy, therefore, has four aspects, which relate to:

- work order planning,

- method selection,

- work site selection, and

- general job decision-making.

It can be real and perceived. Real autonomy refers to the actual degree of the freedom granted to an employee to decide on the organization of their work. Perceived autonomy implies the degree to which an employee believes they have the freedom to organize the work independently. Both real and perceived autonomy are thought to affect engagement. According to self-determination theory, the need for autonomy is one of the three key prerequisites for the development of engagement, in addition to the needs for competence and relatedness (Ryan \& Deci, 2000).

In the digital age, there are numerous changes in job design. Some jobs are no longer performed by people, but by machines instead. This includes the jobs that require certain intellectual efforts, for the needs of which artificial intelligence is applied. There are also changes in traditional job characteristics and the emergence of completely new jobs and tasks as well. The key change is reflected in the fact that technology has enabled the faster and easier collection and processing of large amounts of data, which simultaneously makes some tasks simpler and others more complex. This implies changes in the design of the jobs related to increasing the number of the tasks that one person can perform and increasing their complexity, too. In a complex and uncertain environment, the limitations concerning the mental capacity of each individual as a decision-maker, as well as access to a large amount of information (Nikolic, 2018), are becoming more pronounced, so authority must be delegated in order to avoid mistakes in the decision-making process.
On the other hand, the modern competitive environment requires that organizations be highly agile and innovative in order to survive and develop (Crocitto \& Youssef, 2003; Tallon \& Pinsonneault, 2011; Teece, Peteraf \& Leih, 2016). At the job level, this requires facing challenges and doing creative tasks. It is believed that, with increasing autonomy, employees can successfully respond to these demands. Specifically, autonomy contributes to employees' creativity and responsiveness provided that employees have adequate knowledge and experience, as well as the passion for the job (Liu, Chen \& Yao, 2011; Chang, Huang \& Choi, 2012).

Recently, positive implications of the job crafting have been pointed out. The concept implies a very high level of autonomy, employees' complete freedom to adjust the way they do work at their own discretion, taking into account both personal and organizational needs. This includes changes in the job structure, relationships with other jobs, cognitive requirements, and so on. (Wrzesniewski \& Dutton, 2001). Research has shown that such a high degree of freedom can have an extremely strong motivational potential, which also leads to better performance (Bakker, Tims \& Derks, 2012; McClelland, Leach, Clegg \& McGowan, 2014).

Although most contemporary research studies highlight the important role of autonomy in improving individual performance, satisfaction, innovative behavior, and the passion for the work they do (Kahn, 1990; Saks, 2006; Shantz et al, 2013; Spiegelaere, Van Gyes \& Van Hootegem, 2016; Zhang, Jex, Peng \& Wang, 2017), there are also opposing views that indicate the "dark side" of autonomy, believing that it encourages or at least enables the unethical behavior of the individuals who discretionary decision-making rights are delegated to (Lu, Brockner, Vardi \& Weitz, 2017). However, even these authors point out the fact that the effect of autonomy on unethical behavior is weaker in the individuals who rated autonomy as a business resource very important to them personally. Since the digital working environment, especially in the case of remote working, provides high autonomy 
and low control, it is important to find out whether autonomy has positive or negative consequences in this kind of environment. By examining the effects it has on engagement, it can be assessed whether autonomy has positive implications or not.

In the employees who work with information and communication technologies (ICT), autonomy has proven to increase job satisfaction, because it provides them with the opportunity to make the most of their capacities (Madanagopal \& Thenmozhi, 2015). These are usually complex jobs which require using various skills and the constant collection and processing of new information, given the fact that technology is advancing and competition is fierce. Jobs are based on the maximum use of knowledge and the freedom and flexibility make it easier. Therefore, it can be expected that, in addition to greater job satisfaction, employees will be able to achieve better results. ICT work is mostly done by the professionals who are narrowly specialized, so it is not expected that strict control or any mechanism based on issuing orders and topdown communication will be able to generate good results, because the individuals who do the work are the ones who know the job requirements as well as the ways how to respond to them.

Therefore, the first research hypothesis was developed:

H1: Autonomy has a positive influence on employee engagement in the digital environment.

\section{The moderating effect of remote working}

Remote working is a situation in which the usual office space is not the central location from which the employee performs his/her tasks. The individual, therefore, works in a particular remote location and maintains communication with the rest of the organization through ICT (Bailey \& Kurland, 2002; Pattnaik \& Jena, 2020). In the last year, the COVID-19 pandemic has accelerated the digital transformation of many organizations, which includes, among other things, greater reliance on remote working. This change has found many workers unprepared to adapt to new circumstances and continue to achieve high performance while simultaneously preserving personal well-being. In that sense, the research in engagement as a condition reflecting a good feeling at work and high productivity, as well as the factors that accelerate its development, has become increasingly important.

At first glance, there is naturally greater freedom in the remote workplace in terms of flexibility in organizing their daily tasks. On the one hand, that is true. However, there are certain obstacles, such as the difficulty of maintaining a work-life balance, especially if people choose their family home as a place to work from. Working from home requires a balance between home and family responsibilities, as well as work responsibilities, which challenges autonomy. Research has confirmed that duties towards the household and the family restrict freedom when working from home (Manzo \& Minello, 2020). On the other hand, the freedom of choice in terms of the location, time and manner of working in teleworking conditions helps employees to establish a balance and motivates them (Kossek, Lautsch \& Eaton, 2009).

It is important to emphasize the fact that remote working does not always mean high autonomy. Thus, autonomy is an important precondition of engagement in remote working, perhaps even more important than in the regular office workspace. In a nonremote workplace, there are other possible antecedents of engagement, such as social characteristics of work (e.g. good interpersonal relationships, the perception of belonging to a group/team, feedback from supervisors and others) (May, Gilson \& Harter, 2004; Bakker \& Demerouti, 2007; Bakker \& Bal, 2010). On the other hand engagement in remote working will depend on a small number of possible incentives, among which autonomy stands out as potentially the most important given its dominant role in regular conditions (Christian et al, 2011). Thus, the second research hypothesis reads as follows:

H2: The impact of autonomy on employee engagement in the digital environment is stronger if employees work remotely. 


\section{Research model}

According to the formulated hypotheses, a research model was developed that shows the relationships between the variables (Figure 1).

\section{METHODOLOGICAL FRAMEWORK OF THE EMPIRICAL RESEARCH}

\section{Data collection and processing}

In order to test the hypotheses, an empirical research study was conducted using the survey method. The data were collected from a sample of 158 respondents employed in the IT sector in the territory of the Republic of Serbia from the end of 2020 to the beginning of 2021. A questionnaire based on the existing, wellestablished measurement scales adapted for the needs of the research study was used as a data collection instrument. Autonomy was measured using the three items related to job scheduling autonomy, decisionmaking autonomy and the choice of the working methods. The items were based on the comprehensive job design questionnaire developed by F. P. Morgeson and S. E. Humphrey (2006). The broadly used UWES9 scale was used to measure employee engagement. It includes the following three dimensions: vigor, dedication and absorption (Schaufeli \& Bakker, 2003). The scales were translated into Serbian. Both scales are seven-point scales.

Data processing was performed using the Social Science Statistical Software (SPSS) 25.0 and AMOS 24.0. The sample structure was analyzed using descriptive statistics. To test the reliability of the measurement scales, Cronbach's alpha coefficient was applied, after which confirmatory factor analysis was carried out. The hypotheses were tested using Structural Equation Modeling (SEM).

\section{The sample}

The results of the demographic structure analysis are shown in Table 1. The sample is dominated by the male respondents $(55.7 \%)$ in comparison to the female respondents $(42.4 \%)$ and those who did not want to declare/answer $(1.48 \%)$. The largest number of the respondents are between 20 and 30 years old (44.9\%)

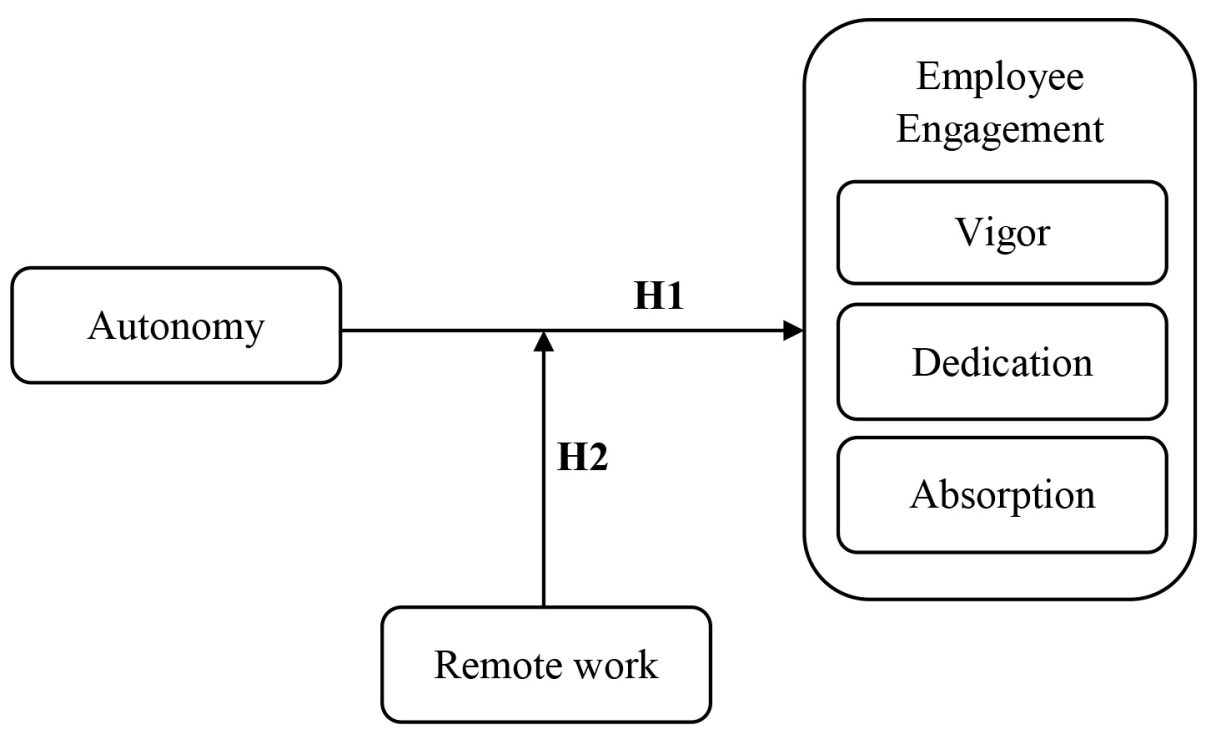

Figure 1 The research model

Source: Author 
and the fewest respondents are classified into the 61-70-years-of-age category (0.6\%). According to their education, the respondents with a university degree predominate $(47.5 \%)$, whereas the smallest number of them has are with a $\mathrm{PhD}(0.6 \%)$.

Table 1 The demographic structure of the sample

\begin{tabular}{l|cc}
\hline Gender & Number & Percentage \\
\hline Male & 88 & $55.7 \%$ \\
Female & 67 & $42.4 \%$ \\
I do not want to declare / & 3 & $1.9 \%$ \\
Data is missing & Number & Percentage \\
\hline Age & 71 & $44.9 \%$ \\
\hline $20-30$ & 68 & $43.0 \%$ \\
$31-40$ & 12 & $7.6 \%$ \\
$41-50$ & 2 & $1.3 \%$ \\
$51-60$ & 1 & $0.6 \%$ \\
61-70 & 4 & $2.5 \%$ \\
Data is missing & Number & Percentage \\
\hline Education level & 29 & $18.4 \%$ \\
\hline High school & 16 & $10.1 \%$ \\
College & 75 & $47.5 \%$ \\
Bachelor's degree & 37 & $23.4 \%$ \\
Master's degree & 1 & $0.6 \%$ \\
PhD/doctoral degree & 0 & 1 \\
Data is missing & 158 & $100 \%$ \\
\hline Total & &
\end{tabular}

Source: Author

\section{RESULTS AND DISCUSSION}

\section{The reliability of the scales and the common method bias}

The reliability of the scales was tested by Cronbach's alpha coefficient (Table 2). All the coefficients are above the threshold of 0.7 (Nunnally, 1978), which makes them highly reliable for further analysis.

Table 2 The reliability of the scales

\begin{tabular}{l|cc}
\hline Scale & $\begin{array}{c}\text { Cronbach's } \\
\text { alpha }\end{array}$ & $\begin{array}{c}\text { Number of } \\
\text { items }\end{array}$ \\
\hline Autonomy & 0.760 & 3 \\
$\begin{array}{l}\text { Engagement - the whole } \\
\text { scale }\end{array}$ & 0.916 & 9 \\
Vigor & 0.913 & 3 \\
Dedication & 0.826 & 3 \\
Absorption & 0.706 & 3 \\
\hline
\end{tabular}

Source: Author

Harman's single factor test was applied in order to test the common method bias. The results showed that the total variance for a single factor was less than $50 \%$, namely $48.51 \%$. Therefore, the common method bias should not be affecting the data.

\section{Structural equation modeling}

In order to test the model validity, confirmatory factor analysis (CFA) was conducted. After removing the items with low factor loadings, below 0.6 (two out of the three items on the Absorption scale), the whole Absorption scale was removed from further analysis because a single item left is all but sufficient to meet the criteria for the CFA. The value $\chi 2 / \mathrm{df}$ is 2.067, which is below the threshold 3 (Carmines \& McIver, 1981). The values CFI $=0.973$, IFI $=0.973$, TLI $=0.957$ and GFI $=0.936$ are above the threshold 0.90 (Byrne, 1998). RMSEA is 0.082, which is below 0.1. The model also shows the satisfactory values of composite reliability (CR), above 0.6 (Bagozzi \& Yi, 1988), and the average variance extracted (AVE), above 0.5 (Fornell \& Larcker, 1981). Table 3 shows the results of the CFA.

Since the model is valid, it is possible to proceed to the hypotheses testing. The results (Table 4) show 
Table 3 Confirmatory factor analysis (CFA)

\begin{tabular}{|c|c|c|c|}
\hline Items & $\begin{array}{l}\text { Factor } \\
\text { loadings }\end{array}$ & AVE & $C R$ \\
\hline Autonomy & & 0.516 & 0.761 \\
\hline $\begin{array}{l}\text { The job allows me to make my own decisions on how to } \\
\text { schedule my work. }\end{array}$ & 0.66 & & \\
\hline The job allows me to make a lot of decisions on my own. & 0.76 & & \\
\hline $\begin{array}{l}\text { The job allows me to make decisions on what methods I use to } \\
\text { complete my work. }\end{array}$ & 0.73 & & \\
\hline Vigor - 1st dimension of engagement & & 0.793 & 0.920 \\
\hline At my work, I feel bursting with energy. & 0.91 & & \\
\hline At my job, I feel strong and vigorous. & 0.91 & & \\
\hline When I get up in the morning, I feel like working. & 0.86 & & \\
\hline Dedication - 2nd dimension of engagement & & 0.608 & 0.820 \\
\hline My job inspires me. & 0.88 & & \\
\hline I am enthusiastic about my job & 0.81 & & \\
\hline I am proud of the work that I do. & 0.63 & & \\
\hline
\end{tabular}

Source: Author

Table 4 Testing the direct impact of autonomy on employee engagement

\begin{tabular}{l|ccc}
\hline \multicolumn{1}{c|}{ Relation } & $\begin{array}{c}\text { Standardized estimate } \\
(\beta)\end{array}$ & Estimate $(\mathrm{B})$ & $\begin{array}{c}\text { Statistical significance } \\
(\mathrm{p} \text {-value })\end{array}$ \\
\hline $\begin{array}{l}\text { Autonomy } \rightarrow \text { Vigor } \\
\left(1^{\text {st }} \text { dimension of Engagement }\right)\end{array}$ & 0.887 & 1.368 & $0.000^{* * *}$ \\
$\begin{array}{l}\text { Autonomy } \rightarrow \text { Dedication } \\
\left(2^{\text {nd }} \text { dimension of Engagement }\right)\end{array}$ & 0.890 & 1.085 & $0.000^{* * *}$ \\
\hline$* * *$ \\
$* 00.001$
\end{tabular}

Source: Author

that autonomy has a statistically significant positive influence on two out of the three engagement dimensions.

After this, the second research hypothesis is tested. Specifically, whether remote working has a moderating impact on the relationship between autonomy and engagement (vigor and dedication) or not is examined. Two groups of employees are identified in the sample, namely those who state that they never work remotely $(\mathrm{n} 1=42)$ and those who work remotely at least once a week $(\mathrm{n} 2=116)$. A comparison is made to determine the statistically significant differences between the two groups in terms of the impact of autonomy on their engagement. Invariance testing (Table 5) shows there are statistically significant differences $(\mathrm{p}=0.078<0.1)$. 
Table 5 Invariance testing in the models

\begin{tabular}{l|cc}
\hline & $\chi^{2}$ & $\mathrm{df}$ \\
\hline Unconstrained model & 171.913 & 48 \\
Constrained model & 177.015 & 50 \\
Difference & 5.102 & 2 \\
$\mathrm{p}$-value & $0.078^{*}$ & \\
\hline${ }^{*} \mathrm{p}<0.1$
\end{tabular}

Source: Author

A regression coefficient comparison test is then conducted to examine whether there are statistically significant differences in the impact of autonomy on engagement between the group of the respondents working remotely and those not working remotely (Table 6).

A statistically significant difference in terms of the impact of autonomy on vigor is found in the analysis of the moderating impact of remote working. Specifically, the positive impact of autonomy on vigor is stronger when employees work remotely $(\beta=1.002)$ than when they do not $(\beta=0.758)$. When the impact of autonomy on dedication is concerned, no statistically significant difference is identified.

\section{Discussion}

The results have shown that autonomy has a positive impact on employee engagement in the digital environment, namely on its two dimensions: vigor and dedication. The impact on the dimension of absorption was not tested, because it became clear during the CFA that that subscale did not meet the conditions for a further analysis. Therefore, Hypothesis 1 is partially supported. The result is complementary to the previous research (Saks, 2006; Christian et al, 2011; Shantz et al, 2013) and indicates that an increase in employee engagement can be expected if autonomy is increased. Unlike the previous research done in various industries, the findings this research has come to are closely related to the information and communication industry, mainly the companies that deal with ICT. These are the activities in which employees' and the entire organization's innovation, responsiveness and proactivity are the key success factors, and autonomy makes it easier for them to achieve these performances.

It can also be concluded that remote working moderates the impact autonomy exerts on vigor as the engagement dimension, so Hypothesis 2 is partially supported. In this way, the relevant role of autonomy in modern organizations is once again confirmed, which was also emphasized in the previous research (Christian et al, 2011), but the step forward made in relation to the previous research refers to the remote working context. This means that autonomy is an even more significant factor of employee engagement in the remote workplace than in the office, at least in terms of vigor. For the people who work remotely, the freedom to choose the exact workplace, the exact methods of work and the exact worktime has proven to be even more important than in regular conditions, given the specifics and the limiting factors of remote working, such as family responsibilities, limited

Table 6 The moderating impact of remote working

\begin{tabular}{l|cccc}
\hline Influence & $\begin{array}{c}\beta-\text { no remote } \\
\text { working }\end{array}$ & $\begin{array}{c}\beta \text {-remote } \\
\text { working }\end{array}$ & $\Delta \beta$ & $\begin{array}{c}\text { p-value of } \\
\text { difference }\end{array}$ \\
\hline $\begin{array}{l}\text { Autonomy } \rightarrow \text { Vigor } \\
\left(1^{\text {st }} \text { dimension of Engagement }\right)\end{array}$ & $0.758 * * *$ & $1.002 * * *$ & -0.244 & $0.042^{* *}$ \\
$\begin{array}{l}\text { Autonomy } \rightarrow \text { Dedication } \\
\left(2^{\text {nd }} \text { dimension of Engagement }\right)\end{array}$ & $0.958 * * *$ & $0.906 * * *$ & 0.052 & 0.414 \\
\hline$* * * p<0,001 * * p<0,05$ & & &
\end{tabular}

Source: Author 
resources, isolation from other colleagues, a reduction in interpersonal interactions, and a lack of social support sometimes.

\section{CONCLUSION}

The paper provides insights into the mutual relationships between autonomy, as one of the most important structural features of work, employee engagement and remote working in specific conditions such as the modern, digital environment, especially characteristic of the companies dealing with ICT, as well as many others going through the digital transformation process in order to adapt to the contemporary economic order and the so-called Industry 4.0 .

Previous research studies have shown that the organizational design that can successfully meet digital transformation demands should be highly agile (Teece, Peteraf \& Leih, 2016). An agile organization must be supported by job redesign, which will be shaped so as to enable fast and quality decisionmaking, as well as high motivation and performance. Faced with rising and changing demands, stress and dissatisfaction may develop in people if jobs are not adequately designed. Conversely, the state of pronounced energy and high performance can develop, such as engagement, and a properly designed job is among the basic drivers of this state (Tims \& Bakker, 2014).

The study has confirmed that the workplace autonomy is an important factor in employee engagement. Employees' discretionary rights to decide on the manner, place and time of performing tasks also increase their perception of the meaningfulness of their work. In addition, if an individual believes that they have control over the work they do and its outcomes, their responsibility for the results increases, as well as their motivation. However, autonomy must be based on individual expertise (Erić Nielsen, 2020), because it is only then that positive effects may be achieved, not only in the engagement context, but also in the development of entrepreneurial behavior and overall organizational performance.

The results also suggest that it might be difficult for employees to respond to rigidly set requirements in terms of time and working conditions in remote conditions when they have to balance between their work and their life and in situations when they might not have all the available resources present in the office (the equipment, social contacts, etc.). It can also be assumed that the importance of autonomy is particularly pronounced in these conditions because the other, alternative drivers of engagement, such as social contacts, support and feedback, are limited.

The research has a scientific contribution in the areas of organizational design and organizational behavior. The significance of autonomy is emphasized as the important characteristics of the so-called "workplace of the future" in the development of engagement - the state of high performance that leads to individuals' greater proactivity and innovation. Previous studies have mainly been done in other industries, so that the knowledge of the autonomyengagement relationship has been deepened by doing research in the IT sector. Speaking in methodological terms, a deeper insight into the effects of autonomy on engagement is provided, as individual effects on the three dimensions of engagement are considered, with a demonstrated positive impact on vigor and dedication. The moderating role of remote working in the relationship between autonomy and engagement is found. Thus, the study expands the existing knowledge and strengthens the foundation for drawing new theoretical conclusions about the job design-engagement relationship in the digital environment.

The study has relevant practical implications. It highlights the importance of employee engagement as a target condition to be achieved in modern conditions in order for not allowing demanding work requirements to lead to stress and burnout, but to an increase in energy, dedication, interest in work, and consequently work performance instead. Furthermore, the study points to one of the job characteristics that is considered the most important 
for achieving engagement. That characteristic is providing freedom and independence to employees in terms of allowing them to make a choice of the way how, the place where and the time at which they will work. The managers who strive to successfully take their company through the digital transformation process should consider the possibility of increasing employee autonomy whenever that may be allowed by the nature of the workplace, employees' knowledge and skills and other situational factors as well.

The paper also has certain limitations. First, the research study was conducted only in Serbia and only in the IT industry, which makes it somewhat difficult to generalize the conclusions. Second, the sample size is always a limitation in the research of this type, so there is a possibility of expanding it in order to increase the reliability of the obtained results. Finally, it should be noted that the survey as a method of data collection has its drawbacks, which include respondents' potential subjectivity. However, it is smaller compared to some other methods (e.g. an interview) since the survey was conducted anonymously.

The findings presented in the paper open up some new questions, providing recommendations for future research. Given the fact that the relatively strong evidence of the positive effects of autonomy on engagement has been established, the question arises as to whether there are exceptional situations in which autonomy will not result in positive effects and which those cases are. Therefore, it is necessary to analyze this relationship in a variety of circumstances in order to examine the potential situational variables that may affect it. It is also possible to include additional indicators of autonomy as a variable so as to include the other aspects of it. In addition, by identifying the moderating role of remote working, the specific context of remote working and its indirect effects should be further examined. Future research should focus on examining the implications of the other structural, cognitive and social characteristics of work on employees as well.

\section{REFERENCE}

Anderson, D., \& Kelliher, C. (2009). Flexible working and engagement: The importance of choice. Strategic HR Review, 8(2), 13-18. doi.org/10.1108/14754390910937530

Bagozzi, R. P., \& Yi, Y. (1988). On the evaluation of structural equation models. Journal of the Academy of Marketing Science, 16(1), 74-94. doi.org/10.1007/BF02723327

Bailey, D. E., \& Kurland, N. B. (2002). A review of telework research: Findings, new directions, and lessons for the study of modern work. Journal of Organizational Behavior, 23(4), 383-400. doi.org/10.1002/job.144

Bakker, A. B., Demerouti, E., Taris, T. W., Schaufeli, W. B., \& Schreurs, P. J. G. (2003). A multigroup analysis of the job demands-resources model in four home care organizations. International Journal of Stress Management, 10(1), 16-38. doi.org/10.1037/1072-5245.10.1.16

Bakker, A. B., \& Demerouti, E. (2007). The job demandsresources model: State of the art. Journal of Managerial Psychology, 22(3), 309-328. doi.org/10.1108/02683940710733115

Bakker, A. B., \& Bal, P. M. (2010). Weekly work engagement and performance: A study among starting teachers. Journal of Occupational and Organizational Psychology, 83(1), 189-206. doi.org/10.1348/096317909X402596

Bakker, A. B., Tims, M., \& Derks, D. (2012). Proactive personality and job performance: The role of job crafting and work engagement. Human Relations, 65(10), 1359-1378. doi:10.1177/0018726712453471

Byrne, B. M. (1998). Structural Equation Modeling with LISREL, PRELIS, and SIMPLIS: Basic Concepts, Applications, and Programming, New Jersey, NJ: Lawrence Erlbaum, Hillsdale.

Carmines, E., \& McIver, J. (1981). Analysing models with unobserved variables: Analysis of covariance structures. In G. Bohmstedt, \& E. Borgatta (Eds.). Social Measurement: Current Issues (pp. 56-77). Beverly Hills, CA: Sage.

Chang, J., Huang, D. W., \& Choi, J. (2012). Is task autonomy beneficial for creativity? Prior task experience and self-control as boundary conditions. Social Behavior and Personality, 40(5), 705-724. dx.doi.org/10.2224/ sbp.2012.40.5.705 
Christian, M. S., Garza, A. S., \& Slaughter, J. E. (2011). Work engagement: A quantitative review and test of its relations with task and contextual performance. Personnel Psychology, 64(1), 89-36. doi.org/10.1111/j.1744-6570.2010.01203.x

Crawford, E. R., LePine, J. A., \& Rich, B. L. (2010). Linking job demands and resources to employee engagement and burnout: A theoretical extension and meta-analytic test. Journal of Applied Psychology, 95(5), 834-848. doi.org/10.1037/ a0019364

Crawford, E. R., Rich, B. L., Buckman, B., \& Bergeron, J. (2014). Antecedents and drivers of employee engagement. In C. Truss, R. Delbridge, K. Alfes, A. Shantz, \& E. Soane (Eds.). Employee engagement in theory and practice (pp. 57-81). London \& New York, UK \& NY: Routledge, Taylor \& Francis Group.

Crocitto, M., \& Youssef, M. (2003). The human side of organizational agility. Industrial Management \& Data Systems, 103(6), 388-397. doi.org/10.1108/02635570310479963

Demerouti, E., Bakker, A. B., Nachreiner, F., \& Schaufeli, W. B. (2001). The job demands-resources model of burnout. Journal of Applied Psychology, 86(3), 499-512. doi.org/10.1037/00219010.86.3.499

Erić Nielsen, J. (2020). Korporationo preduzetništvo. Kragujevac, RS: Ekonomski fakultet Univerziteta u Kragujevcu.

Erić Nielsen, J., Babić, V., Stojanović-Aleksić, V., \& Nikolić, J. (2019). Driving forces of employees' entrepreneurial intentions - Leadership style and organizational structure. Management: Journal Of Sustainable Business And Management Solutions In Emerging Economies, 24(3), 59-71. doi:10.7595/10.7595/management.fon.2019.0020

Fornell, C., \& Larcker, D. F. (1981). Evaluating structural equation models with unobservable variables and measurement error. Journal of Marketing Research, 18(1), 3980. doi.org/10.2307/3151312

Golden, T. D., \& Gajendran, R. S. (2019). Unpacking the role of a telecommuter's job in their performance: Examining job complexity, problem solving, interdependence and social support. Journal of Business and Psychology, 34(1), 55-69. doi.org/10.1007/s10869-018-9530-4

Halbesleben, J. R. B. (2010). A meta-analysis of work engagement: Relationships with burnout, demands, resources, and consequences. In A. B. Bakker, \& M. P. Leiter (Eds.). Work engagement: A handbook of essential theory and research (pp. 102-117). New York, NY: Psychology Press.
Humphrey, S. E., Nahrgang, J. D., \& Morgeson, F. P. (2007). Integrating motivational, social, and contextual work design features: A meta-analytic summary and theoretical extension of the work design literature. Journal of Applied Psychology, 92(5), 1332-1356. doi.org/10.1037/00219010.92.5.1332

Johns, T. (2012). Employee Engagement. In: S. Taylor, \& C. Woodhams (Eds.). Managing People and Organisations (pp. 83-110). London, UK: Chartered Institute of Personnel and Development.

Kahn, W. A. (1990). Psychological conditions of personal engagement and disengagement at work. Academy of Management Journal, 33(4), 692-724. doi.org/10.2307/256287

Kossek, E. E., Lautsch, B. A., \& Eaton, S. C. (2009). “Good teleworking": Under what conditions does teleworking enhance employees' well-being? In Y. Amichai-Hamburger (Ed.). Technology and Psychological Well-being (pp. 148-173). Cambridge, UK: Cambridge University Press.

Kwon, K., \& Kim, T. (2020). An integrative literature review of employee engagement and innovative behavior: Revisiting the JD-R model. Human Resource Management Review, 30(2), 1-18. doi.org/10.1016/j.hrmr.2019.100704

Liu, D., Chen, X.-P., \& Yao, X. (2011). From autonomy to creativity: A multilevel investigation of the mediating role of harmonious passion. Journal of Applied Psychology, 96(2), 294-309. doi.org/10.1037/a0021294

Lu, J. G., Brockner, J., Vardi, Y., \& Weitz, E. (2017). The dark side of experiencing job autonomy: Unethical behavior. Journal of Experimental Social Psychology, 73, 222-234. doi.org/10.1016/j.jesp.2017.05.007

Macey, W. H., Schneider, B., Barbera, K. M., \& Young, S. A. (2009). Talent Management Essentials. Employee Engagement: Tools for Analysis, Practice, and Competitive Advantage. Hoboken, NJ: Wiley-Blackwell.

Madanagopal, D., \& Thenmozhi, S. (2015). Relationship between job autonomy and job satisfaction among male employees in the ITeS sector from Chennai city. Annamalai International Journal of Business Studies \& Research, 73-78.

Manzo, L. K. C., \& Minello, A. (2020). Mothers, childcare duties, and remote working under COVID-19 lockdown in Italy: Cultivating communities of care. Dialogues in Human Geography, 10(2), 120-123. doi.org/10.1177/2043820620934268 
May, D. R., Gilson, R. L., \& Harter, L. M. (2004). The psychological conditions of meaningfulness, safety and availability and the engagement of the human spirit at work. Journal of Occupational and Organizational Psychology, 77(1), 11-37. doi.org/10.1348/096317904322915892

McClelland, G. P., Leach, D. J., Clegg, C. W., \& McGowan, I. (2014). Collaborative crafting in call centre teams. Journal of Occupational and Organizational Psychology, 87(3), 464-486. doi:10.1111/joop.12058

Morgeson, F. P., \& Humphrey, S. E. (2006). The work design questionnaire (WDQ): Developing and validating a comprehensive measure for assessing job design and the nature of work. Journal of Applied Psychology, 91(6), 13211339. doi.org/10.1037/0021-9010.91.6.1321

Nikolić, J. (2018). Biases in the decision-making process and possibilities of overcoming them. Economic Horizons, 20(1), 43-57. doi:10.5937/ekonhor1801045N

Nunnally, J. C. (1978). Psychometric Theory. 2nd Edition, New York, NY: McGraw-Hill.

Pattnaik, L., \& Jena, L. K. (2020). Mindfulness, remote engagement and employee morale: Conceptual analysis to address the "new normal". International Journal of Organizational Analysis, 29(4), 873-890. oi.org/10.1108/IJOA06-2020-2267

Radošević, V., Jelić, D., Matanović, J. i Popov, B. (2018). Zahtevi posla i resursi na radu kao prediktori izgaranja na radu i radne angažovanosti: Glavnii interaktivni efekti. Primenjena psihologija, 11(1), 105-125. doi:10.19090/pp.2018.1.105-125

Ryan, R. M., \& Deci, E. L. (2000). Self-determination theory and the facilitation of intrinsic motivation, social development, and well-being. American Psychologist, 55(1), 68-78. doi.org/10.1037/0003-066X.55.1.68

Saks, A. M. (2006). Antecedents and consequences of employee engagement. Journal of Managerial Psychology, 21(7), 600-619. doi.org/10.1108/02683940610690169

Saks, A. M., \& Gruman, J. A. (2014). What do we really know about employee engagement? Human Resource Development Quarterly, 25(2), 155-182. doi.org/10.1002/hrdq.21187

Salanova, M., Agut, S., \& Peiró, J. M. (2005). Linking organizational resources and work engagement to employee performance and customer loyalty: The mediation of service climate. Journal of Applied Psychology, 90(6), 1217-1227. doi.org/10.1037/0021-9010.90.6.1217
Savovic, S., Zlatanovic, D., \& Nikolic, J. (2021). Technology acquisitions as a supporting tool for improving companies' innovative potential. Economic Horizons, 23(1), 3-17. doi:10.5937/ekonhor2101003S

Schaufeli, W. B., \& Bakker, A. B. (2003). Test manual for the Utrecht Work Engagement Scale. Unpublished manuscript, Utrecht University, The Netherlands. Retrieved May 15, 2021, from http://www.schaufeli.com

Schaufeli, W. B., \& Bakker, A. B. (2010). Defining and measuring work engagement: Bringing clarity to the concept. In A. B. Bakker, \& M. P. Leiter (Eds.). Work Engagement: A Handbook of Essential Theory and Research (pp. 10-24). New York, NY: Hove and New York, Psychology Press, Taylor \& Francis Group.

Shantz, A., Alfes, K., Truss, C., \& Soane, E. (2013). The role of employee engagement in the relationship between job design and task performance, citizenship and deviant behaviours. The International Journal of Human Resource Management, 24(13), 2608-2627. doi.org/10.1080/09585192.20 12.744334

Shuck, B., Ghosh, R., Zigarmi, D., \& Nimon, K. (2012). The jingle jangle of employee engagement: Further exploration of the emerging construct and implications for workplace learning and performance. Human Resource Development Review, 12(1), 11-35. doi:10.1177/1534484312463921

Simić, M., Slavković, M., \& Ognjanović, J. (2020). Information literacy competencies in digital age: Evidence from smalland-medium-sized enterprises. In V. Domanović, \& D. Zlatanović (Eds.). Proceedings of the 6th International Scientific Conference on Contemporary Issues in Economics, Business and Management (EBM 2020) (pp. 105-114). Kragujevac, RS: Faculty of Economics University of Kragujevac, The Republic of Serbia.

Sinha, K. K., \& Van de Ven, A. H. (2005). Designing work within and between organizations. Organization Science, 16(4), 389-408. doi.org/10.1287/orsc.1050.0130

Spiegelaere, S., Van Gyes, G., \& Van Hootegem, G. (2016). Not all autonomy is the same. Different dimensions of job autonomy and their relation to work engagement \& Innovative work behavior. Human Factors and Ergonomics in Manufacturing, 26(4), 515-527. doi.org/10.1002/hfm.20666

Stojanovic-Aleksic, V. (2016). Followers in the organizational leadership process: From attribution to shared leadership. Economic Horizons, 18(2), 135-148. doi:10.5937/ ekonhor1602139S 
Tallon, P. P., \& Pinsonneault, A. (2011). Competing perspectives on the link between strategic information technology alignment and organizational agility: Insights from a mediation model. MIS Quarterly, 35(2), 463-486. doi.org/10.2307/23044052

Teece, D., Peteraf, M., \& Leih, S. (2016). Dynamic capabilities and organizational agility: Risk, uncertainty, and strategy in the innovation economy. California Management Review, 58(4), 13-35. doi.org/10.1525/cmr.2016.58.4.13

Thomson, P. (2008). The business benefits of flexible working. Strategic HR Review, 7(2), 17-22. doi:10.1108/14754390810853129

Tims, M., \& Bakker, A. B. (2014). Job design and employee engagement. In C. Truss, K. Alfes, R. Delbridge, A. Shantz, \& A. Soane (Eds.). Employee Engagement in Theory and Practice (pp. 131-148) London \& New York, UK \& NY: Routledge, Taylor \& Francis Group

Wollard, K. K., \& Shuck, B. (2011). Antecedents to employee engagement: A structured review of the literature. Advances in Developing Human Resources, 13(4), 429-446. doi.org/10.1177/1523422311431220
Wrzesniewski, A., \& Dutton, J. (2001). Crafting a job: Revisioning employees as active crafters of their work. Academy of Management Review, 26(2), 179-201. doi.org/10.5465/amr.2001.4378011

Youssef-Morgan, C. M., \& Bockorny, K. M. (2014). Engagement in the context of positive psychology. In C. Truss, R. Delbridge, K. Alfes, A. Shantz, \& E. Soane (Eds.). Employee Engagement in Theory and Practice (pp. 36-56). London \& New York, UK \& NY: Routledge, Taylor \& Francis Group.

Zhang, W., Jex, S. M., Peng, Y., \& Wang, D. (2017). Exploring the effects of job autonomy on engagement and creativity: The moderating role of performance pressure and learning goal orientation. Journal of Business and Psychology, 32(3), 235-251. doi.org/10.1007/s10869-016-9453-x

\section{Received on $14^{\text {th }}$ Jul 2021, after revision, accepted for publication on $25^{\text {th }}$ November 2021 Published online on $6^{\text {th }}$ December 2021}

Aleksandra Boskovic is a Teaching Assistant at the Faculty of Economics, University of Kragujevac. Currently, she is a $\mathrm{PhD}$ candidate at the same university. She teaches the following courses: Organization of Enterprise, Corporate Social Responsibility and Leadership. The areas of her research interest are organizational design, organizational behavior, employee engagement and corporate social responsibility. 


\title{
AUTONOMIJA I ANGAŽOVANOST ZAPOSLENIH U DIGITALNOJ ERI: MODERATORSKA ULOGA RADA NA DALJINU
}

\author{
Aleksandra Bošković* \\ Ekonomski fakultet Univerziteta u Kragujevcu
}

U eri digitalizacije, tradicionalni faktori uspeha preduzeća dovedeni su u pitanje, pa je potrebno preispitati ustaljene obrasce rada i ispitati nove načine za stvaranje održive vrednosti. Obzirom da ljudi, kao nosioci znanja, predstavljaju ključne pokretače vrednosti, neophodno je istražiti načine za unapređenje njihovog potencijala. Cilj istraživanja u radu jeste da se pokaže da autonomija doprinosi unapređenju angažovanosti zaposlenih $u$ digitalnom okruženju, a posebno u uslovima rada na daljinu. $U$ tom smislu, objašnjen je koncept angažovanosti zaposlenih, kao stanja visoke energije, posvećenosti i okupiranosti poslom i ukazano je na moguće načine za unapređenje angažovanosti, kroz povećanje autonomije. Empirijskim istraživanjem je potvrđeno da autonomija pozitivno utiče na energiju i posvećenost, kao dimenzije angažovanosti, kao i da je uticaj na energiju jači kod zaposlenih koji rade na daljinu.

Ključne reči: autonomija, dizajn posla, angažovanost zaposlenih, rad na daljinu, digitalno okruženje, organizacioni dizajn

\section{JEL Classification: M20, M12, J28}

\section{UVOD}

Psihološka povezanost zaposlenih sa poslom predstavlja polje istraživanja koje dobija na značaju u ekonomiji znanja i u uslovima ubrzanog tehnološkog napretka, kada ljudski kapital postaje sve bitniji pokretač konkurentnosti preduzeća i privrede. Razvoj sofisticiranih veština, koje dovode do superiornih performansi, zavisi od spleta složenih organizacionih,

* Korespondencija: A. Bošković, Ekonomski fakultet Univerziteta u Kragujevcu, Liceja Kneževine Srbije 3, 34000 Kragujevac, Republika Srbija; e-mail: aboskovic@kg.ac.rs intelektualnih, psiholoških, socioloških i drugih faktora.

$\mathrm{U}$ eri znanja, inovacija i tehnološkog napretka, konkurenska prednost preduzeća zavisi od generisanja i implementacije novih ideja, kao i primene novih tehnologija (Simić, Slavković \& Ognjanović, 2020; Savović, Zlatanović \& Nikolić, 2021). Obzirom da su ljudi ključni nosioci znanja i kapaciteta za inovacije, savremene organizacije zahtevaju od zaposlenih visoku posvećenost, ulaganje i energičnost, kako bi, u izrazito dinamičnom okruženju, stvarali održivu vrednost. Česte promene i izraženi pritisci 
na ljude da se brzo prilagođavaju istim, obavljajući sve složenije i kognitivno zahtevnije zadatke, mogu dovesti do oprečnih efekata. Prema teoriji zahteva posla i resursa (Job Demands-Resources Theory), zahtevi mogu biti shvaćeni kao izazovi ili smetnje, što će implicirati pozitivan ili negativan odgovor zaposlenih. Negativne reakcije su povezane sa preopterećnošću, stresom i izgaranjem na poslu, dok se pozitivne reakcije očekuju u slučaju kada zaposleni razvijaju visoku angažovanost, odnosno, energičnost, posvećenost i okupiranost poslom (Bakker \& Demerouti, 2007).

Brojni faktori formiraju okolnosti u kojima se reakcije zaposlenih oblikuju, ali se među najznačajnijim pretpostavkama angažovanosti izdvaja organizacioni kontekst, posebno način na koji je posao dizajniran. Prethodna istraživanja ukazuju na bitnu ulogu autonomije na radnom mestu (Kahn, 1990; Saks, 2006; Christian, Garza \& Slaughter, 2011; Shantz, Alfes, Truss \& Soane, 2013; Radošević, Jelić, Matanović i Popov, 2018). Autonomija proizilazi iz većeg stepena decentralizacije, tako da je karakteristična za savremene strukture koje su ravnije, odnosno, imaju manji broj hijerarhijskih nivoa. Ovakve strukture pogoduju razvoju inovativnosti i preduzetničkog kapaciteta $u$ preduzeću (Erić Nielsen, Babić, Stojanović-Aleksić \& Nikolić, 2019; Erić Nielsen, 2020). Sloboda, koju zaposleni imaju na svom poslu, podstiče kreativnost i omogućava lakše prilagođavanje promenama. U tom kontekstu, razvili su se i novi modeli liderstva koji podržavaju ideju da deo moći, pod određenim uslovima, treba biti prenet na same sledbenike, kako bi oni i čitava organizacija ostvarivali nadprosečne rezultate (Stojanović-Aleksić, 2016).

Ovo je naročito važno u eri digitalizacije, koju karakterišu eksponencijalne promene $\mathrm{i}$ to ne samo $u$ razvoju tehnologije, nego i $u$ ekonomiji i društvu. Postojeća istraživanja nisu dovoljno empirijski ispitala ulogu autonomije u ovakvom, specifičnom kontekstu. Iako teorija ukazuje na benefite autonomije, kako u pogledu zadovoljenja određenih psiholoških potreba, tako i opšte dobrobiti pojedinca, retko se uzima u obzir digitalno okruženje kao kontekst ispitivanja veze između autonomije i angažovanosti. U uslovima u kojima je veza između ljudi i mašina postala skoro podjednako važna kao međuljudski odnosi, potrebno je preispitivati tradicionalne mehanizme podsticanja angažovanja i tražiti nove načine ili faktore koji posredno mogu doprineti izgradnji dugoročne i održive angažovanosti zaposlenih, koja će doprineti njihovoj ličnoj satisfakciji, boljem osećaju na poslu i $\mathrm{u}$ životu, ali i porastu produktivnosti i inovativnosti preduzeća (Halbesleben, 2010; Christian et al, 2011; Kwon \& Kim, 2020).

Imajući u vidu značaj problemskog područja, predmet istraživanja $u$ radu jeste povezanost autonomije na radnom mestu i angažovanosti zaposlenih $\mathrm{u}$ digitalnom okruženju. U ovom radu, pod digitalnim okruženjem podrazumeva se ono poslovno okruženje u kojem se intenzivno koristi IKT u obavljanju zadataka. Shodno ovako opredeljenom predmetu, osnovni cilj istraživanja jeste da se utvrdi da li i na koji način autonomija utiče na angažovanost zaposlenih u sektoru informacionih tehnologija (IT), koji predstavlja primer delatnosti sa izraženom dimenzijom digitalnog okruženja.

U vezi sa autonomijom, važno je razmotriti i jedan od relativno novijih trendova $u$ organizacionom dizajnu, koji se ističe u digitalnom okruženju, a odnosi se na rad na daljinu. Savremena tehnologija je omogućila, a novije forme organizacionog dizajna podržale, implementaciju ideje da fizička lokacija za obavljanje posla nije uvek bitna i da neki poslovi mogu da se obavljaju i van kancelarije, na lokaciji koju zaposleni sam bira (kuća, stan, biblioteka, park, kafeterija). Ovaj trend se još brže razvio usled pandemije Covid-19, zbog koje su neke vlade uvele čak i obavezu za firme da omoguće svojim zaposlenima rad na daljinu, konkretno, od kuće (Pattnaik \& Jena, 2020). Ovu mogućnost je, svakako, lakše primeniti na poslovima koji se obavljaju na računaru i nisu visoko zavisni od lokacije/ličnog kontakta, kao što je slučaj, između ostalog, u IT sektoru. Iako rad na daljinu ima svoje nedostatke, vezane za izolovanost i smanjenje socijalnih interakcija, istraživanja, ipak, ukazuju 
na dominantnost pozitivnih implikacija. Među najznačajnijim koristima koje se ostvaruju prilikom rada na daljinu, ističu se: niži troškovi (Thomson, 2008), prijatniji ambijent u kome se zaposleni lakše posvećuje obavljanju kompleksnih zadataka (Golden \& Gajendran, 2019), veća satisfakcija i odgovorno ponašanje, što vodi i većoj angažovanosti (Anderson \& Kelliher, 2009). Osnovna prednost rada na daljinu, trebalo bi da bude veća sloboda izbora u pogledu mesta, vremena i načina obavljanja zadataka. Ukoliko zaposlenima nije omogućena autonomija prilikom rada na daljinu, pozitivne implikacije ovog koncepta se, možda, neće ispoljiti. Zbog toga, poseban cilj istraživanja jeste utvrđivanje moderatorskog uticaja rada na daljinu u odnosu između autonomije i angažovanosti zaposlenih.

U radu je primenjena kvalitativna i kvantitativna metodologija. Shodno složenoj, dinamičnoj i višeznačnoj prirodi razmatranih fenomena, oslonac je u primeni sistemskog mišljenja. Primenjeni su metodi analize i sinteze, apstrakcije i konkretizacije, kao i indukcije i dedukcije. Kada je kvantitativna metodologija u pitanju, korišćen je statistički metod. Podaci su prikupljeni anketom, a analizirani različitim statističkim tehnikama.

Pored Uvoda i Zaključka, rad se sastoji iz: pregleda literature, na osnovu kojeg su razvijene istraživačke hipoteze, i empirijskog istraživanja, kojim su hipoteze testirane. U okviru pregleda literature, razjašnjena je suština koncepta angažovanosti i istaknuti su ključni faktori koji utiču na razvoj angažovanosti zaposlenih u savremenim preduzećima. Zatim je posebno elaborirana uloga dizajna posla, kao faktora angažovanosti, a onda i autonomije kao ključne karakteristike dizajna posla, čiji su efekti na angažovanost najviše izraženi $\mathrm{u}$ digitalnom poslovnom okruženju. Ukazano je na moguće moderatorske efekte rada na daljinu, kao posebne okolnosti $u$ kojim se pozitivni efekti autonomije na angažovanost povećavaju. Objašnjena je metodologija, a zatim su predstavljeni i diskutovani dobijeni rezultati.

\section{PREGLED LITERATURE I RAZVOJ HIPOTEZA}

\section{Koncept angažovanosti zaposlenih}

Angažovanost predstavlja relativno nov pojam u naučnoj literaturi, ali je u menadžerskoj praksi poznat već decenijama. Najpoznatije konsultantske kompanije širom sveta za jedan od ključnih ciljeva postavljaju unapređenje angažovanosti zaposlenih, kao faktora koji povećava profitabilnost kroz povećanje produktivnosti, ali i satisfakcije zaposlenih i klijenata (Schaufeli \& Bakker, 2010). Kasnija istraživanja su pokazala da angažovanost ima niz pozitivnih implikacija kako na individualnom, tako i na organizacionom nivou. Iz perspektive pozitivne psihologije, angažovanost na poslu doprinosi potrebi pojedinaca da vode ispunjen život u svakom aspektu (Youssef-Morgan \& Bockorny, 2014). Stoga se može očekivati da su zaposleni, koji razvijaju visok stepen angažovanosti, i zadovoljniji. Postoje i određeni pokazatelji boljeg fizičkog i mentalnog zdravlja kod visoko angažovanih radnika (Johns, 2012; Shuck, Ghosh, Zigarmi \& Nimon, 2012). Angažovani pojedinci su, uglavnom, produktivniji, a pokazuju i veći stepen kreativnosti i proaktivnosti. Organizacije koje uspevaju da razviju visoku angažovanost kod zaposlenih, mogu očekivati i bolje finansijske rezultate $\mathrm{u}$ dugom roku (Macey, Schneider, Barbera \& Young, 2009). Smatra se da upravo ova dualna dimenzija koristi od angažovanosti (za pojedince i za organizaciju), čini ovaj fenomen toliko značajnim.

Koncept dobija pažnju u literaturi od kada je W. Kahn (1990, 700) definisao angažovanost kao „istovremeno uključivanje i ispoljavanje ličnosti (preffered self) prilikom rada i ponašanja na poslu, koje promoviše povezanost sa poslom i drugima, ličnu prisutnost (fizičku, kognitivnu i emocionalnu) i aktivno ostvarivanje performansi". Autor vidi angažovanost kao potpuno unošenje sebe, fizički, kognitivno i emocionalno, u posao ili radnu ulogu. Osoba uspostavlja neku vrstu simbiotske veze sa poslom koji radi i to je čini srećnom. 
U literaturi postoji relativno visok stepen saglasnosti o tome da je angažovanost jedinstven i distinktivan motivacioni koncept, koji se može opisati kroz tri dimenzije (Salanova, Agut \& Peiró, 2005) - energičnost, posvećenost i apsorbciju. Energičnost (vigor) se odnosi na visok nivo spremnosti da se uloži napor u rad, bez obzira na potencijalne teškoće. Posvećenost ili predanost (dedication) ukazuje na visoku inspirisanost poslom, entuzijazam i osećaj ponosa zbog obavljenih zadataka. Apsorbcija se prevodi i kao okupiranost (absorption) i podrazumeva potpunu udubljenost $\mathrm{u}$ radne zadatke i aktivnosti, kao i teškoću koju osoba ima da prestane sa radom.

Glavna specifičnost koncepta angažovanosti, naročito kao svojevrsnog pokazatelja uspeha preduzeća, jeste $u$ tome što se ne može narediti, a vrlo teško se može i neopsredno kontrolisati. Kreira se kroz dugoročno građenje odnosa sa ljudima u organizaciji i razvoj prijatnog radnog okruženja. Od nastanka koncepta, istraživači nastoje da utvrde sve relevantne pretpostavke, odnosno, faktore angažovanosti, kako bi pronašli što konkretnije i detaljnije odgovore na pitanje kako izgraditi angažovanu radnu snagu. Pregledom literature, identifikovani su određeni faktori angažovanosti, koji se mogu svrstati u dve široke kategorije: individualni i organizacioni faktori.

Individualni faktori se odnose na različite koncepte povezane sa ličnošću pojedinca, kao što su lični resursi i karakteristike ličnosti. Prema teoriji poslovnih zahteva i resursa (Job Demands - Resources Theory), lični resursi, koji se ističu kao ključni faktori angažovanosti, su: samoefikasnost, odnosno, verovanje u sopstvenu sposobnost da se efikasno odgovori na zahteve različitih situacija, kao i optimizam, to jest, pogled na svet, odnosno, verovanje da će se stvari odvijati u željenom pravcu, što povećava entuzijazam i želju za ulaganjem sebe u radnu ulogu (Crawford, Rich, Buckman \& Bergeron, 2014). Pored ličnih resursa, smatra se da postoje i određene lične karakteristike koje utiču na angažovanost, iako dokazi za ovu pretpostavku nisu čvrsto teorijski utemeljeni i empirijski dokazani kroz veći broj istraživanja. Određene studije su pokazale da karakteristike među kojima su savesnost, proaktivnost i pozitivan afekt, imaju pozitivnu korelaciju sa angažovanošću
(Saks \& Gruman, 2014). Takođe, određeni empirijski podaci ukazuju na to da otvorenost i ekstrovertnost predstavljaju najznačajnije faktore angažovanosti među karakteristikama koje čine grupu velikih pet (Wollard \& Shuck, 2011). Imajući u vidu važnost ličnih karakteristika kao faktora organizacionog ponašanja, ali i ponašanja i života ljudi, uopšte, u literaturi postoji veliki nedostatak istraživanja ovih pitanja.

Organizacioni faktori angažovanosti zaposlenih se mogu javiti na nivou posla, grupe/tima i organizacije. Među najznačajnima su: karakteristike posla, liderstvo, organizaciona pravda i organizaciona podrška. Karakteristike posla se smatraju najznačajnijim faktorima koji utiče na angažovanost zaposlenih. Iako sve karakteristike posla mogu uticati na angažovanost, na osnovu rezultata postojećih empirijskih istraživanja se mogu istaći sledeće: autonomija, kompleksnost posla, rešavanje problema, raznovrsnost zadataka, povratna informacija iz posla i od drugih, sklad ličnost-posao, mogućnosti za razvoj, socijalna podrška (Crawford, LePine \& Rich, 2010; Christian et al, 2011).

\section{Značaj dizajna posla za razvoj angažovanosti}

Dizajn posla predstavlja sistem kojim se organizuje obavljanje određenog posla (Sinha \& Van de Ven, 2005, 390). Brojna su svojstva kojima se jedan posao može opisati, ali jedna od najsveobuhvatnijih klasifikacija izdvaja tri osnovne dimenzije posla (Morgeson \& Humphry, 2006): dimenziju zadatka, kojom se opisuje struktura zadataka koji čine posao (strukturalna dimenzija), dimenziju znanja, koja sadrži karakteristike znanja potrebnih za izvršavanje zadataka (kognitivna dimenzija) i dimenziju kojom se opisuju socijalne interakcije na poslu (socijalna dimenzija). Strukturalna dimenzija obuhvata sledeće karakteristike: autonomija, raznovrsnost, značaj i identitet zadataka, kao i povratna sprega sa poslom. Kognitivna dimenzija uključuje: složenost posla, stepen obrade informacija, rešavanje problema raznovrsnim veštinama i specijalizaciju. Socijalna dimenzija odnosi se na socijalnu podršku, međuzavisnost sa kolegama, interakcije i povratne 
informacije (Morgeson \& Humphry, 2006). Pored tri osnovne dimenzije posla, dizajn posla uključuje i dimenziju konteksta (ergonomija, fizički uslovi rada itd.), kao i karakteristike samih zaposlenih. U ovom radu, fokus će biti na tri osnovne dimenzije posla.

Polaznu, teorijsko-metodološku osnovu za razmatranje veze između dizajna posla i angažovanosti zaposlenih, postavlja teorija zahteva posla i resursa, koja polazi od pitanja zašto su neki ljudi iscrpljeni poslom, dok drugi osećaju entuzijazam i energiju prilikom rada? Odgovor na ovo pitanje traži se u konceptu dizajna posla. Teorija predstavlja proširenje modela zahteva posla i resursa koji su postavili E. Demerouti, A. B. Bakker, F. Nachreiner i W. B. Schaufeli (2001), a dalje razvili A. B. Bakker i E. Demerouti (2007). Istraživači su identifikovali ograničenja postojećih modela dobrobiti zaposlenih i stresa na radnom mestu (model zahtevi-kontrola i model (ne)ravnoteže ulaganja i nagrada), koji su bili previše pojednostavljeni i statični, jer su se bavili ograničenim brojem promenljivih i nisu se odnosili na sve ljude ili delatnosti. Kako bi se prevazišla uočena ograničenja, model zahteva posla i resursa je obuhvatio širok spektar varijabli i zasnovan je na pretpostavci da svako zanimanje može imati specifične faktore rizika povezane sa stresom na poslu i angažovanošću, a ovi faktori se mogu podeliti u dve opšte grupe, nazvane zahtevi i resursi.

Zahtevi su fizički, psihološki, socijalni ili organizacioni aspekti posla, koji zahtevaju stalne napore ili veštine i zbog toga su povezani sa određenim fiziološkim i/ ili psihološkim troškovima - stalni radni pritisak, nepovoljno fizičko okruženje i emocionalno zahtevne interakcije sa klijentima (Bakker \& Demerouti, 2007, 312). Iako poslovni zahtevi ne moraju nužno biti negativni, oni uvek zahtevaju izvestan napor. Ponekad, ukoliko zaposleni nije u stanju da odgovori na zahteve, to može dovesti do negativnih posledica, kao što su stres, izgaranje i zdravstveni problemi. Zahtevi mogu biti klasifikovani kao: izazovi (radne odgovornosti, rokovi, obim posla), ili smetnje (emocionalni/afektivni sukob, organizaciona politika) (Crawford et al, 2010). Prema tome, odnos između zahteva posla i angažovanosti zavisi od vrste zahteva, tako da su izazovi povezani pozitivno, a smetnje su negativno povezane sa angažovanjem.

Poslovni resursi se definišu kao „oni fizički, psihološki, socijalni ili organizacioni aspekti posla koji doprinose postizanju radnih ciljeva ili smanjuju poslovne zahteve i povezane fiziološke i psihološke troškove ili podstiču lični rast, učenje i razvoj" (Bakker \& Demerouti, 2007, 312). Resursi nisu isključivo usmereni ka rešavanju zahteva, već imaju i motivacionu ulogu. Interni faktori motivacije dolaze iz resursa koji podstiču lični rast zaposlenih, dok eksterni faktori motivacije potiču iz onih resursa koji su ključni instrumenti za postizanje radnih ciljeva. Resursi za posao se mogu nalaziti na nivou organizacije, u međuljudskim i socijalnim odnosima, kao i na nivou dizajna poslova. Neki od primera resursa na nivou posla su: autonomija, kreativni zadaci, podrška od strane nadređenog i kolega.

Stres i izgaranje na poslu će se pojaviti kada su zahtevi visoki, a dostupni resursi niski. Međutim, resursi mogu umanjiti negativne efekte zahteva (Bakker, Demerouti, Taris, Schaufeli \& Schreurs, 2003) i podstaći motivaciju i angažovanje.

\section{Autonomija kao faktor angažovanosti zaposlenih u IT sektoru}

Autonomija može biti shvaćena kao „sloboda koju pojedinac ima u obavljanju posla" (Humphrey, Nahrgang \& Morgeson, 2007, 1333), ili kao stepen do koga posao dozvoljava slobodu, nezavisnost $\mathrm{i}$ diskreciona prava pojedinca $\mathrm{u}$ pogledu izbora redosleda radnih aktivnosti, metoda rada i odlučivanja (Morgeson \& Humphrey, 2006). Prema tome, autonomija ima četiri aspekta, koja se odnose na:

- planiranje redosleda rada,

- izbor metoda rada,

- izbor mesta za rad, i

- generalno odlučivanje o poslu.

Autonomija može biti stvarna i percipirana. Stvarna autonomija se odnosi na realno dodeljen stepen 
slobode zaposlenom za odlučivanje o organizovanju svog posla, a percipirana autonomija označava stepen $\mathrm{u}$ kome zaposleni veruje da ima slobodu da samostalno organizuje svoj posao. Smatra se da i stvarna i percipirana autonomija utiču na angažovanost. Prema teoriji samodeterminacije, potreba za autonomijom je jedan od tri ključna preduslova za razvoj angažovanosti, pored potreba za razvojem kompetentnosti i za povezivanjem (Ryan \& Deci, 2000).

$\mathrm{U}$ eri digitalizacije dolazi do brojnih promena $\mathrm{u}$ dizajnu poslova. Polazeći od toga da neke poslove više ne obavljaju ljudi, nego mašine, uključujući i poslove koji zahtevaju intelektualne napore, za čije potrebe se primenjuje veštačka inteligencija, preko promena $\mathrm{u}$ tradicionalnim karakteristikama posla, do pojave potpuno novih poslova i zadataka. Ključna promena se ogleda u tome što je tehnologija omogućila brže i lakše prikupljanje i obradu velike količine informacija, što, istovremeno, neke zadatke čini jednostavnijim, a druge složenijim. To implicira promene u dizajnu poslova koji se odnose na povećanje broja zadataka koje jedna osoba može obaviti, ali i povećanje njihove kompleksnosti. U složenom i neizvesnom okruženju, ograničenja koja se tiču mentalnih kapaciteta svakog pojedinca, kao donosioca odluka, kao i pristupa velikom broju informacija (Nikolić, 2018), postaju sve izraženiji, pa se autoritet nužno mora delegirati kako ne bi došlo do grešaka u procesu odlučivanja i smanjenja kvaliteta odluka.

S druge strane, savremeno konkurentsko okruženje zahteva od organizacija visoku agilnost i inovativnost kako bi opstale i razvijale se (Crocitto \& Youssef, 2003; Tallon \& Pinsonneault, 2011; Teece, Peteraf \& Leih, 2016). Na nivou posla, to znači brzo suočavanje sa izazovima i visoku kreativnost. Smatra se da, sa povećanjem autonomije, zaposleni mogu uspešno odgovoriti na ove izazove. Tačnije, autonomija doprinosi kreativnosti i respozivnosti zaposlenih, pod uslovima da zaposleni imaju adekvatno znanje i iskustvo, kao i strast prema poslu (Liu, Chen \& Yao, 2011; Chang, Huang \& Choi, 2012).

$\mathrm{U}$ novije vreme, ističu se pozitivne implikacije koncepta „krojenja posla“ (job crafting), koji podrazumeva izrazito visok nivo autonomije, odnosno, potpunu slobodu zaposlenih da način rada prilagođavaju po sopstvenom nahođenju, a imajući $\mathrm{u}$ vidu kako lične, tako i organizacione potrebe. Koncept uključuje promene u strukturi posla, vezama sa drugim poslovima, kognitivnim zahtevima itd, (Wrzesniewski \& Dutton, 2001). Istraživanja su pokazala da ovako visok stepen slobode može imati izuzetno snažan motivacioni potencijal, što dovodi i do boljeg učinka (Bakker, Tims \& Derks, 2012; McClelland, Leach, Clegg \& McGowan, 2014).

Iako većina savremenih istraživanja ističe važnu ulogu autonomije u unapređenju performansi pojedinaca, njihovog zadovoljstva, inovativnog ponašanja i strasti prema poslu koji obavljaju (Kahn, 1990; Saks, 2006; Shantz et al, 2013; Spiegelaere, Van Gyes \& Van Hootegem, 2016; Zhang, Jex, Peng \& Wang, 2017), ima i suprotstavljenih stavova koji ističu "mračnu stranu" autonomije, smatrajući da ona podstiče, ili bar omogućava neetičko ponašanje pojedinaca kojima su delegirana diskreciona prava odlučivanja o poslu (Lu, Brockner, Vardi \& Weitz, 2017). Međutim, čak i ova istraživanja ističu da je efekat autonomije na neetičko ponašanje slabiji kod pojedinaca koji su ocenili autonomiju kao poslovni resurs koji im je lično veoma važan. Kako digitalno radno okruženje pruža pojedincima visok stepen autonomije i vrlo malu kontrolu od strane nadređenih, naročito kada je u pitanju rad na daljinu, bitno je proceniti da li se, u ovakvoj sredini, javljaju pozitivne ili negativne posledice. Procenom efekata na angažovanost, može se oceniti da li autonomija ima pozitivne implikacije.

Kod zaposlenih, koji se bave informacionokomunikacionim tehnologijama (IKT), pokazano je da autonomija povećava satisfakciju poslom, jer im pruža mogućnost da maksimalno iskoriste svoje kapacitete (Madanagopal \& Thenmozhi, 2015). Reč je, najčešće, o složenim poslovima, koji zahtevaju upotrebu raznovrsnih veština i stalno prikupljanje i obradu novih podataka, s obzirom da tehnologija napreduje, a konkurencija je izražena. Poslovi su zasnovani na maksimalnoj upotrebi znanja, a sloboda u pogledu prilagođavanja, načina rada, to olakšava. Zbog toga, može se očekivati da pored većeg zadovoljstva poslom, zaposleni mogu da ostvare i bolje rezultate. 
Poslove u oblasti IKT, uglavnom, obavljaju stručnjaci koji su usko specijalizovani, tako da se ne očekuje da stroga kontrola, ili bilo koji mehanizam zasnovan na izdavanju naloga i komuniciranju s-vrha-ka-dnu, može dati dobre rezultate, jer pojedinci koji obavljaju posao, zapravo, najbolje poznaju potrebe i zahteve posla, kao i načine da se na njih odgovori.

Shodno navedenom, razvijena je osnovna istraživačka hipoteza:

H1: Autonomija pozitivno utiče na nivo angažovanosti zaposlenih $\mathrm{u}$ digitalnom okruženju.

\section{Moderatorski efekat rada na daljinu}

Pod radom na daljinu podrazumeva se situacija u kojoj uobičajeni kancelarijski prostor nije centralna lokacija sa koje zaposleni obavlja radne zadatke. Pojedinac, dakle, radi na određenoj udaljenoj lokaciji, a održava komunikaciju sa ostatkom organizacije putem informaciono-komunikacione tehnologije (Bailey \& Kurland, 2002; Pattnaik \& Jena, 2020). Tokom 2020, pandemija COVID-19 je ubrzala digitalnu transformaciju mnogih organizacija, koja, između ostalog, uključuje i veće oslanjanje na rad na daljinu. Ovakva promena je mnoge radnike zatekla nespremnim da se brzo prilagode novim okolnostima i da nastave da ostvaruju visoke performanse, uz istovremeno očuvanje lične dobrobiti. U tom smislu, istraživanje angažovanosti, kao stanja koje reflektuje dobar osećaj na poslu i visoku produktivnost, kao i faktora koji pospešuju razvoj ovakvog stanja, dobija sve veći značaj.

Na prvi pogled, reklo bi se da u uslovima rada na daljinu prirodno postoji veća sloboda na radnom mestu, u smislu veće fleksibilnosti u organizovanju svojih dnevnih zadataka. S jedne strane, to jeste tačno. Međutim, s druge strane, javljaju se određene smetnje kao što je teškoća održavanja balansa između posla i života, naročito ukoliko zaposleni biraju svoj porodični dom kao mesto za rad. Rad od kuće zahteva balansiranje između kućnih i porodičnih obaveza, kao i radnih obaveza, čime je autonomija dovedena u pitanje. Istraživanja su potvrdila da dužnosti prema domaćinstvu i porodici ograničavaju slobodu prilikom rada od kuće (Manzo \& Minello, 2020). $S$ druge strane, sloboda izbora u pogledu lokacije, vremena i načina rada, u uslovima rada na daljinu, pomaže zaposlenima da uspostave balans između posla i života i motiviše ih (Kossek, Lautsch \& Eaton, 2009).

Samim tim, bitno je naglasiti da rad na daljinu ne podrazumeva uvek i visok stepen autonomije, te da je autonomija važan preduslov angažovanosti prilikom rada na daljinu, možda čak i važniji nego u situaciji kada zaposleni rade u kancelariji. Ukoliko zaposleni rade u kancelariji, postoji mogućnost oslanjanja i na druge moguće prediktore angažovanosti, kao što je niz faktora iz kategorije socijalnih karakteristika posla - dobri odnosi sa kolegama, percepcija pripadnosti grupi/timu, povratne informacije od nadređenog i drugih ljudi (May, Gilson \& Harter, 2004; Bakker \& Demerouti, 2007; Bakker \& Bal, 2010). S druge strane, u uslovima rada na daljinu, angažovanost će zavisiti od manjeg broja mogućih podsticajnih faktora, među kojima se autonomija može izdvojiti kao potencijalno najznačajniji, imajući u vidu njenu dominantnu ulogu i u regularnim uslovima (Christian et al, 2011).

Prema tome, razvijena je druga istraživačka hipoteza:

H2: Uticaj autonomije na angažovanost zaposlenih u digitalnom okruženju je jači ukoliko zaposleni rade na daljinu.

\section{Istraživački model}

Shodno formulisanim hipotezama, formiran je konceptualni istraživački model koji prikazuje odnose između istraživačkih varijabli (Slika 1).

\section{METODOLOŠKI OKVIR EMPIRIJSKOG ISTRAŽIVANJA}

\section{Prikupljanje i obrada podataka}

Kako bi se postavljene hipoteze testirale, sprovedeno je empirijsko istraživanje metodom ankete. Podaci 


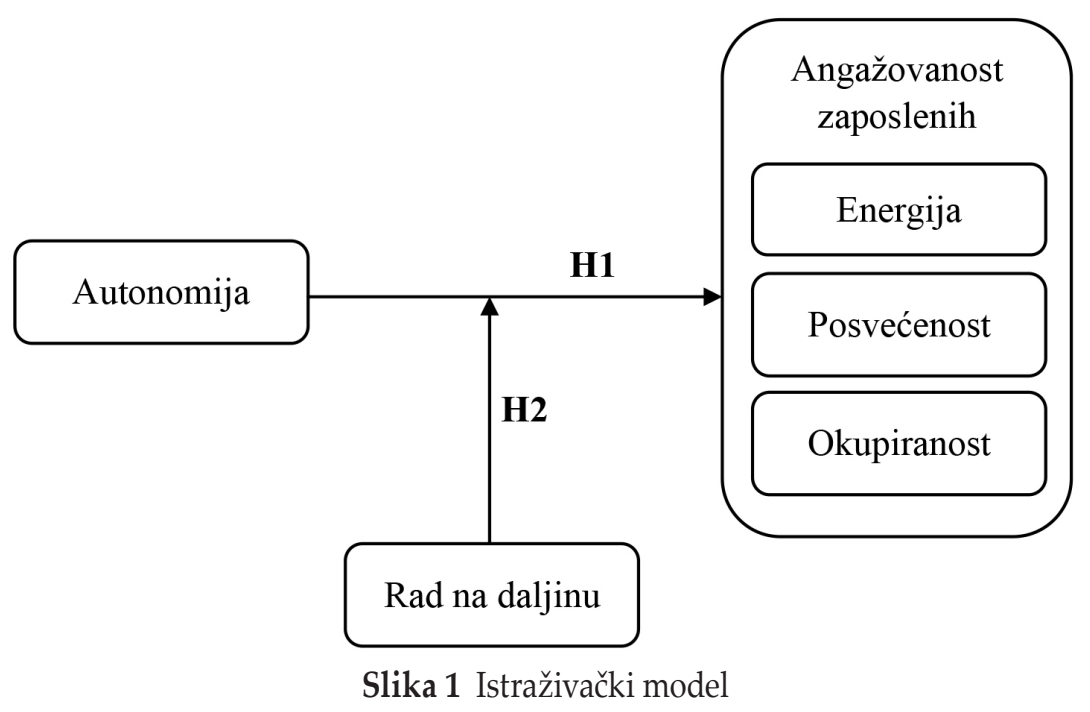

Izvor: Autor

su prikupljeni, na osnovu uzorka od 158 ispitanika zaposlenih u IT sektoru, na teritoriji Republike Srbije (RS), u periodu kraj 2020 - početak 2021. Kao instrument za prikupljanje podataka, korišćen je upitnik, baziran na postojećim, dobro utemeljenim mernim skalama, koje su prilagođene za potrebe istraživanja. Autonomija je merena pomoću tri stavke - autonomija raspoređivanja poslova, autonomija odlučivanja i autonomija koja se odnosi na izbor metoda rada. Pitanja su preuzeta iz sveobuhvatnog upitnika o dizajnu posla, koji su razvili F. P. Morgeson i S. E. Humphrey (2006). Za merenje angažovanosti zaposlenih, korišćen je upitnik UWES-9, koji se najčešće koristi $u$ istraživanjima ovog tipa i meri tri dimenzije angažpvanosti - energiju, posvećenost i okupiranost (Schaufeli \& Bakker, 2003). Skale su sedmostepene.

Obrada podataka izvršena je korišćenjem odgovarajućih statističkih metoda i tehnika u Social Science Statistical Software-u (SPSS) 25.0 i AMOS 24.0. Struktura uzorka je analizirana pomoću deskriptivnih statističkih mera. Za testiranje pouzdanosti mernih skala, primenjen je Cronbach-ov koeficijen alfa, a zatim je sprovedena i konfirmatorna faktorska analiza. Hipoteza je testirana primenom modeliranja strukturalnih jednačina (Structural Equation Modelling - SEM).

\section{Uzorak}

Uzorak je analiziran prema demografskim karakteristikama ispitanika, a rezultati su prikazani u Tabeli 1. Može se videti da dominiraju ispitanici muškog pola (55,7\%), u odnosu na ispitanike ženskog pola $(42,4 \%)$ i one koji su nisu želeli da odgovore (1,48\%). Najveći broj ispitanika ima između 20 i 30 godina $(44,9 \%)$, a najmanje je ispitanika u kategoriji 61-70 godina $(0,6 \%)$. Prema obrazovnoj strukturi, preovlađuju ispitanici sa završenim fakultetom $(47,5 \%)$, dok je najmanje doktora nauka $(0,6 \%)$.

\section{REZULTATI I DISKUSIJA}

\section{Pouzdanost mernih skala i pristrasnost metoda}

Pouzdanost mernih skala korišćenih u upitniku testirana je izračunavanjem Cronbach-ovog koeficijenta alfa (Tabela 2). Sve skale imaju koeficijent iznad preporučene granične vrednosti od 0,7 (Nunnally, 1978), tako da mogu biti ocenjene kao visoko pouzdane za korišćenje u daljem istraživanju. 
Tabela 1 Demografska struktura uzorka

\begin{tabular}{l|cc}
\hline Pol & Broj & Procenat \\
\hline Muški & 88 & $55,7 \%$ \\
Ženski & 67 & $42,4 \%$ \\
Ne želim da se izjasnim / & 3 & $1,9 \%$ \\
Nedostaju podaci & Broj & Procenat \\
\hline Godine starosti & 71 & $44,9 \%$ \\
\hline $20-30$ & 68 & $43,0 \%$ \\
$31-40$ & 12 & $7,6 \%$ \\
$41-50$ & 2 & $1,3 \%$ \\
$51-60$ & 1 & $0,6 \%$ \\
61-70 & 4 & $2,5 \%$ \\
Nedostaju podaci & Broj & Procenat \\
\hline Nivo obrazovanja & 29 & $18,4 \%$ \\
\hline Srednja škola & 16 & $10,1 \%$ \\
Viša škola & 75 & $47,5 \%$ \\
Fakultet & 37 & $23,4 \%$ \\
Master/Magistar & 1 & $0,6 \%$ \\
Doktor nauka & 0 & 1 \\
Nedostaju podaci & 158 & $100 \%$ \\
\hline Ukupno & &
\end{tabular}

Izvor: Autor

Tabela 2 Pouzdanost mernih skala

\begin{tabular}{l|cc}
\hline Skala & $\begin{array}{c}\text { Koeficijent } \\
\text { alfa }\end{array}$ & $\begin{array}{c}\text { Broj } \\
\text { stavki }\end{array}$ \\
\hline Autonomija & 0,760 & 3 \\
Angažovanost - cela skala & 0,916 & 9 \\
Energija & 0,913 & 3 \\
Posvećenost & 0,826 & 3 \\
Okupiranost (apsorpcija) & 0,706 & 3 \\
\hline
\end{tabular}

Izvor: Autor

Pristrasnost metoda (common method bias) testirana je primenom Harman-ovog testa (Harman's single factor test). Rezultati testa su pokazali da je ukupna varijansa za jedan faktor manja od 50\%, tačnije, iznosi
$48,51 \%$, što govori o tome da pristrasnost ne utiče na podatke.

\section{Modeliranje strukturalnih jednačina}

Kako bi se procenila validnost modela, primenjena je konfirmatorna faktorska analiza. Nakon eliminisanja stavki sa faktorskim opterećenjima ispod 0,6 (dve od tri stavke iz podskale Okupiranost), eliminisana je cela podskala Okupiranost jer jedna preostala stavka nije dovoljan uslov za sprovođenje komfirmatorne faktorske analize. Zatim je izračunata vrednost pokazatelja $\chi 2 / \mathrm{df}$, koja iznosi 2,067, što je manje od preporučene maksimalne vrednosti od 3 (Carmines \& McIver, 1981). Vrednosti pokazatelja CFI = 0,973, IFI = $0,973, \mathrm{TLI}=0,957 \mathrm{i} \mathrm{GFI}=0,936$ više su od preporučene minimalne vrednosti od 0,90 (Byrne, 1998). Vrednost koeficijenta RMSEA iznosi 0,082, što je ispod preporučene gornje granice od 0,1 . Takođe, model pokazuje zadovoljavajuće vrednosti kompozitne pouzdanosti (CR), iznad 0,6 (Bagozzi \& Yi, 1988) i prosečne izdvojene varijanse (AVE), koja je iznad 0,5 (Fornell \& Larcker, 1981). Tabela 3 pokazuje rezultate konfirmatorne faktorske analize.

S obzirom na to da je model validan, može se pristupiti testiranju hipoteza primenom modela strukturalnih jednačina. Rezultati (Tabela 4) pokazuju da autonomija ima statistički značajan, pozitivan uticaj na dve, od tri dimenzije angažovanosti zaposlenih.

Zatim je testirana druga istraživačka hipoteza. Ispitano je da li rad na daljinu ima moderatorski uticaj na vezu između autonomije i angažovanosti (energije i posvećenosti) zaposlenih. U uzorku su identifikovane dve grupe zaposlenih - oni koji su se izjasnili da nikada ne rade na daljinu $\left(n_{1}=42\right)$ i oni koji bar jednim radnim danom obavljaju poslove van radnog mesta $\left(\mathrm{n}_{2}=116\right)$. Kako bi se utvrdile statistički značajne razlike između ove dve grupe, izvršeno je poređenje u pogledu uticaja autonomije na stepen njihove angažovanosti. Rezultati testa invarijantnosti (Tabela 5) je pokazao da postoje statistički značajne razlike između posmatranih grupa $(p=0,078<0,1)$. 
Tabela 3 Rezultati konfirmativne faktorske analize (CFA)

\begin{tabular}{|c|c|c|c|}
\hline Konstatacije & $\begin{array}{c}\text { Faktorska } \\
\text { opterećenja }\end{array}$ & AVE & CR \\
\hline Autonomija & & 0,516 & 0,761 \\
\hline $\begin{array}{l}\text { Posao mi dozvoljava da sam(a) donosim odluke o načinu } \\
\text { raspoređivanja aktivnosti i vremena. }\end{array}$ & 0,66 & & \\
\hline Posao mi omogućava da donosim mnoge odluke samostalno. & 0,76 & & \\
\hline $\begin{array}{l}\text { Posao mi omogućava da samostalno odlučim koje ću metode } \\
\text { primenjivati u radu. }\end{array}$ & 0,73 & & \\
\hline Energija - 1. dimenzija angažovanosti & & 0,793 & 0,920 \\
\hline Na poslu sam pun/a energije. & 0,91 & & \\
\hline Dok obavljam svoj posao, osećam se snažno i poletno. & 0,91 & & \\
\hline Kad ujutru ustanem, jedva čekam da radim svoj posao. & 0,86 & & \\
\hline Posvećenost - 2. dimenzija angažovanosti & & 0,608 & 0,820 \\
\hline Moj posao me inspiriše. & 0,88 & & \\
\hline Osećam entuzijazam u vezi sa svojim poslom. & 0,81 & & \\
\hline Ponosim se poslom koji radim. & 0,63 & & \\
\hline
\end{tabular}

Izvor: Autor

Tabela 4 Testiranje direktnog uticaja autonomije na angažovanost zaposlenih

\begin{tabular}{l|ccc}
\hline \multicolumn{1}{c|}{ Relacija } & $\begin{array}{c}\text { Standardizovana } \\
\text { procena }(\beta)\end{array}$ & Procena (B) & $\begin{array}{c}\text { Statistička značajnost } \\
(\mathrm{p})\end{array}$ \\
\hline $\begin{array}{l}\text { Autonomija } \rightarrow \text { Energija } \\
\text { (1. dim. Angažovanosti) }\end{array}$ & 0,887 & 1,368 & $0,000^{* * *}$ \\
$\begin{array}{l}\text { Autonomija } \rightarrow \text { Posvećenost } \\
\text { (2. dim. angažovanosti) }\end{array}$ & 0,890 & 1,085 & $0,000^{* * *}$ \\
\hline
\end{tabular}

$* * * p<0,001$

Izvor: Autor

Tabela 5 Testiranje invarijantnosti u modelima

\begin{tabular}{l|cc}
\hline & $\chi 2$ & df \\
\hline Neograničen model & 171,913 & 48 \\
Ograničen model & 177,015 & 50 \\
Razlika & 5,102 & 2 \\
p-vrednost & $0,078^{*}$ & \\
\hline
\end{tabular}

$* p<0,1$

Izvor: Autor
Narednim ispitivanjem, sproveden je test kojim se porede koeficijenti regresije, kako bi se ispitalo da li postoje statistički značajne razlike u uticaju autonomije na angažovanost između grupe ispitanika koji rade na daljinu i onih koji ne rade na daljinu. Rezultati su prikazani u Tabeli 6.

Analizom moderatorskog uticaja rada na daljinu, identifikovana je statistički znaćajna razlika u pogledu uticaja autonomije na energiju, kao prvu dimenzije 
angažovanosti zaposlenih. Tačnije, utvrđeno je da je pozitivan uticaj autonomije na energičnost zaposlenih jači u slučaju kada zaposleni rade na daljinu $(\beta=1,002)$, nego kada ne rade na daljinu $(\beta=0,758)$. Kada je reč o uticaju autonomije na posvećenost, nije identifikovana statistički značajna razlika između grupe ispitanika koji su se izjasnili da primenjuju rad na daljinu i onih koji ne rade na daljinu.

\section{Diskusija rezultata istraživanja}

Rezultati istraživanja su pokazali da autonomija ima pozitivan uticaj na angažovanost zaposlenih $\mathrm{u}$ digitalnom okruženju, odnosno, na njene dve dimenzije: energiju i posvećenost. Uticaj na dimenziju okupiranosti poslom nije testiran, jer se prilikom konfirmatorne faktorske analize ispostavilo da ova subskala ne ispunjava uslove za dalju analizu. Shodno tome, hipoteza 1 je delimično potvrđena. Ovakav rezultat je u skladu sa prethodnim istraživanjima (Saks, 2006; Christian et al, 2011; Shantz et al, 2013) i ukazuje na to da se sa povećanjem autonomije može očekivati i porast angažovanosti zaposlenih. Za razliku od prethodnih istraživanja, koja su sprovedena u raznovrsnim delatnostima, saznanja do kojih se dolazi ovim istraživanjem usko su vezana za delatnost Informisanja i komunikacija, $\mathrm{i}$ to pretežno firme koje se bave informacionokomunikacionim tehnologijama. Ovo su delatnosti u kojima su inovativnost, brzo reagovanje na izazove i proaktivnost zaposlenih, kao i cele organizacije, ključi faktori uspeha, a autonomija upravo olakšava postizanje ovih performansi.

Može se zaključiti da je rad na daljinu moderator uticaja autonomije na energiju zaposlenih, kao jednu dimenziju angažovanosti, tako da je hipoteza 2 delimično potvrđena. To znači da je autonomija još značajniji faktor angažovanosti zaposlenih $u$ uslovima rada na daljinu, nego prilikom rada $u$ kancelariji, bar što se tiče energije kao jedne važne komponente koncepta angažovanosti. Na ovaj način, još je jednom potvrđena relevantna uloga autonomije u savremenim organizacijama, koja je istaknuta i u prethodnim istraživanjima (Christian et al, 2011), ali se iskorak $u$ odnosu na prethodna istraživanja odnosi na kontekst rada na daljinu. Za osobe koje rade na daljinu, sloboda izbora tačnog mesta na kojem će raditi, načina i vremena za rad, pokazali se se još bitnijom nego u regularnim uslovima, imajući u vidu specifičnosti i ograničavajuće faktore rada na daljinu, kao što su porodične obaveze, ograničenost resursa, izolovanost iz kolektiva, redukcija međuljudskih interakcija, a ponekad i socijalne podrške.

\section{ZAKLJUČAK}

Rad pruža uvide u međusobne odnose autonomije, kao jedne od najznačajnijih strukturalnih karakteristika posla, angažovanosti zaposlenih i rada na daljinu, $\mathrm{u}$ specifičnim uslovima kakvo je savremeno, digitalno okruženje, posebno svojstveno preduzećima koje se bave informaciono-komunikacionim tehnologijama, ali i mnogim drugim koja prolaze kroz proces digitalne transformacije $u$ cilju prilagođavanja savremenom ekonomskom poretku i tzv. industriji 4.0.

Prethodna istraživanja su pokazala da organizacioni dizajn, koji može uspešno da odgovori na zahteve digitalne transformacije, treba da bude baziran

Tabela 6 Moderatorski uticaj rada na daljinu

\begin{tabular}{l|cccc}
\hline Uticaj & $\begin{array}{c}\beta \text {-rad iz } \\
\text { kancelarije }\end{array}$ & $\begin{array}{c}\beta \text {-rad na } \\
\text { daljinu }\end{array}$ & $\Delta \beta$ & $\begin{array}{c}\text { p-vrednost } \\
\text { razlike }\end{array}$ \\
\hline Autonomija $\rightarrow$ Energija (1. dim. Angažovanosti) & $0,758^{* * *}$ & $1,002 * * *$ & $-0,244$ & $0,042^{* *}$ \\
Autonomija $\rightarrow$ Posvećenost (2. dim. angažovanosti) & $0,958 * * *$ & $0,906 * * *$ & 0,052 & 0,414 \\
\hline$* * * \mathrm{p}<0,001 * * \mathrm{p}<0,05$ & & &
\end{tabular}

Izvor: Autor 
na visokoj agilnosti (Teece, Peteraf \& Leih, 2016). Kreiranje agilne organizacije mora biti podržano redizajnom poslova, koji će biti oblikovani tako da omogućavaju brzo i kvalitetno odlučivanje, kao i visoku motivaciju i performanse zaposlenih. Suočeni sa visokim i promenljivim zahtevima, ljudi mogu razviti stres i nezadovoljstvo, ukoliko poslovi nisu adekvatno dizajnirani. Suprotno tome, može se razviti stanje izražene energičnosti i visokih performansi, kao što je angažovanost, a među osnovnim pokretačima ovakvog stanja je pravilno dizajniran posao (Tims \& Bakker, 2014).

Istraživanjem, koje je sprovedeno $\mathrm{u}$ ovom radu, potvrđeno je da autonomija na radnom mestu predstavlja bitan faktor angažovanosti zaposlenih. Diskreciona prava zaposlenih da odlučuju o načinu, mestu i vremenu obavljanja zadataka, povećavaju i njihovu percepciju svrsishodnosti posla koji rade. Pored toga, ukoliko pojedinac veruje da ima kontrolu nad poslom i ishodima svojih aktivnosti, povećava se i njegova odgovornost za ostvarene rezultate, kao i motivacija. Međutim, bitno je naglasiti da autonomija treba biti zasnovana na znanju i ekspertizi (Erić Nielsen, 2020), jer jedino pod tim uslovom može dati pozitivne efekte, ne samo u kontekstu angažovanosti, nego i razvoja preduzetničkog ponašanja i sveukupnih performansi organizacije.

Rezultati upućuju i na zaključak da zaposlenima može biti teško da odgovore na rigidno zadate poslovne zahteve $u$ pogledu vremena i načina rada u uslovima rada na daljinu, kada moraju balansirati između vremena posvećenog poslu i životu, kao i onda kada nemaju sve raspoložive resurse koji su prisutni u kancelariji (oprema, socijalni kontakti itd.). Takođe, može se pretpostaviti da je značaj autonomije posebno izražen u ovim uslovima zbog toga što su dejstva drugih, alternativnih pokretača angažovanosti, kao što su socijalni kontakti, podrška i povratne informacije, ograničeni.

Istraživanje ima naučni doprinos $u$ oblastima organizacionog dizajna i organizacionog ponašanja. Istaknut je značaj autonomije, kao bitne karakteristike "radnog mesta budućnosti" u razvoju angažovanosti - stanja visokih performansi koje vodi većoj proaktivnosti i inovativnosti pojedinaca. Prethodne studije su, uglavnom, rađene $\mathrm{u}$ drugim delatnostima, tako da su, sprovođenjem istraživanja u IT sektoru, produbljena postojeća saznanja o autonomiji kao faktoru angažovanosti. U metodološkom smislu, obezbeđen je dublji uvid $u$ efekte autonomije na angažovanost, s obzirom da su razmatrani pojedinačni efekti na tri dimenzije angažovanosti, pri čemu je dokazan pozitivan uticaj na energiju i posvećenost. Takođe, istraživanjem je utvrđena moderatorska uloga rada na daljinu u odnosu između autonomije i angažovanosti, čime su postojeća znanja proširena i učvršćen je temelj za izvođenje novih teorijskih zaključaka o uzročno-posledičnim vezama između dizajna posla i angažovanosti zaposlenih $u$ digitalnom okruženju.

Praktične implikacije istraživanja odnose se, prevashodno, na pružanje uvida menadžmentu savrmenih organizacija u značaj angažovanosti, kao ciljnog stanja koje treba postići kod zaposlenih u savremenim uslovima, kako izraženi poslovni zahtevi ne bi doveli do stresa i izgaranja, nego do povećanja energije, posvećenosti, zainteresovanosti za posao, a posledično i radnog učinka. Takođe, rad ukazuje na jednu od karakteristika posla koja se smatra najznačajnijom za postizanje angažovanosti, a to je pružanje slobode i nezavisnosti zaposlenima u pogledu izbora načina, mesta i vremena za rad. Menadžeri koji nastoje da uspešno sprovedu svoje preduzeće kroz proces digitalne transformacije, treba da razmotre mogućnost povećanja autonomije zaposlenih, kad god to dozvoljavaju priroda radnog mesta, znanje i sposobnosti zaposlenih, kao i drugi situacioni faktori.

Rad ima i određena ograničenja. Pre svega, istraživanje je sprovedeno samo u Republici Srbiji i samo u IT sektoru, što, donekle, otežava generalizaciju zaključaka. Veličina uzorka uvek predstavlja ograničenje $u$ istraživanjima ovog tipa, tako da postoji mogućnost njegovog proširenja u cilju povećanja pouzdanosti dobijenih rezultata. Takođe, treba istaći i da anketa kao metod prikupljanja podataka ima svoje nedostatke, među kojima se može izdvojiti potencijalna subjektivnost ispitanika prilikom davanja odgovora. Ipak, ona je manja u odnosu na 
neke druge metode (intervju), obzirom da je anketa sprovedena anonimno.

Saznanja do kojih se došlo u radu otvaraju i neka nova pitanja, pružajući smernice za buduća istraživanja. S obzirom da su utvrđeni relativno čvrsti dokazi o pozitivnim efektima autonomije na angažovanost, postavlja se pitanje da li postoje izuzetne situacije $u$ kojima autonomija neće dati pozitivne efekte i koji su to slučajevi. Dakle, potrebno je analizirati ovu vezu u raznovrsnim okolnostima, kako bi se ispitale potencijalne situacione varijable koje na nju mogu uticati. Takođe, mogućejeuključiti i dodatne indikatore autonomije kao varijable, u cilju obuhvatanja i drugih njenih aspekata. Pored toga, identifikovanjem moderatorske uloge rada na daljinu, u odnosu između autonomije i angažovanosti zaposlenih, otvoren je niz pitanja vezanih za razumevanje specifičnog konteksta rada na daljinu i njegovih posrednih efekata i na druge veze između karakteristika posla i individualih ishoda. Buduća istraživanja bi trebalo da budu usmerena ka ispitivanju implikacija drugih strukturalnih, kognitivnih i socijalnih karakteristika posla za zaposlene.

\section{REFERENCE}

Anderson, D., \& Kelliher, C. (2009). Flexible working and engagement: The importance of choice. Strategic HR Review, 8(2), 13-18. doi.org/10.1108/14754390910937530

Bagozzi, R. P., \& Yi, Y. (1988). On the evaluation of structural equation models. Journal of the Academy of Marketing Science, 16(1), 74-94. doi.org/10.1007/BF02723327

Bailey, D. E., \& Kurland, N. B. (2002). A review of telework research: Findings, new directions, and lessons for the study of modern work. Journal of Organizational Behavior, 23(4), 383-400. doi.org/10.1002/job.144

Bakker, A. B., Demerouti, E., Taris, T. W., Schaufeli, W. B., \& Schreurs, P. J. G. (2003). A multigroup analysis of the job demands-resources model in four home care organizations. International Journal of Stress Management, 10(1), 16-38. doi.org/10.1037/1072-5245.10.1.16
Bakker, A. B., \& Demerouti, E. (2007). The job demandsresources model: State of the art. Journal of Managerial Psychology, 22(3), 309-328. doi.org/10.1108/02683940710733115

Bakker, A. B., \& Bal, P. M. (2010). Weekly work engagement and performance: A study among starting teachers. Journal of Occupational and Organizational Psychology, 83(1), 189-206. doi.org/10.1348/096317909X402596

Bakker, A. B., Tims, M., \& Derks, D. (2012). Proactive personality and job performance: The role of job crafting and work engagement. Human Relations, 65(10), 1359-1378. doi:10.1177/0018726712453471

Byrne, B. M. (1998). Structural Equation Modeling with LISREL, PRELIS, and SIMPLIS: Basic Concepts, Applications, and Programming, New Jersey, NJ: Lawrence Erlbaum, Hillsdale.

Carmines, E., \& McIver, J. (1981). Analysing models with unobserved variables: Analysis of covariance structures. In G. Bohmstedt, \& E. Borgatta (Eds.). Social Measurement: Current Issues (pp. 56-77). Beverly Hills, CA: Sage.

Chang, J., Huang, D. W., \& Choi, J. (2012). Is task autonomy beneficial for creativity? Prior task experience and self-control as boundary conditions. Social Behavior and Personality, 40(5), 705-724. dx.doi.org/10.2224/ sbp.2012.40.5.705

Christian, M. S., Garza, A. S., \& Slaughter, J. E. (2011). Work engagement: A quantitative review and test of its relations with task and contextual performance. Personnel Psychology, 64(1), 89-36. doi.org/10.1111/j.1744-6570.2010.01203.x

Crawford, E. R., LePine, J. A., \& Rich, B. L. (2010). Linking job demands and resources to employee engagement and burnout: A theoretical extension and meta-analytic test. Journal of Applied Psychology, 95(5), 834-848. doi.org/10.1037/ a0019364

Crawford, E. R., Rich, B. L., Buckman, B., \& Bergeron, J. (2014). Antecedents and drivers of employee engagement. In C. Truss, R. Delbridge, K. Alfes, A. Shantz, \& E. Soane (Eds.). Employee engagement in theory and practice (pp. 57-81). London \& New York, UK \& NY: Routledge, Taylor \& Francis Group.

Crocitto, M., \& Youssef, M. (2003). The human side of organizational agility. Industrial Management \& Data Systems, 103(6), 388-397. doi.org/10.1108/02635570310479963 
Demerouti, E., Bakker, A. B., Nachreiner, F., \& Schaufeli, W. B. (2001). The job demands-resources model of burnout. Journal of Applied Psychology, 86(3), 499-512. doi.org/10.1037/00219010.86.3.499

Erić Nielsen, J. (2020). Korporationo preduzetništvo. Kragujevac, RS: Ekonomski fakultet Univerziteta u Kragujevcu.

Erić Nielsen, J., Babić, V., Stojanović-Aleksić, V., \& Nikolić, J. (2019). Driving forces of employees' entrepreneurial intentions - Leadership style and organizational structure. Management: Journal Of Sustainable Business And Management Solutions In Emerging Economies, 24(3), 59-71. doi:10.7595/10.7595/management.fon.2019.0020

Fornell, C., \& Larcker, D. F. (1981). Evaluating structural equation models with unobservable variables and measurement error. Journal of Marketing Research, 18(1), 3980. doi.org/10.2307/3151312

Golden, T. D., \& Gajendran, R. S. (2019). Unpacking the role of a telecommuter's job in their performance: Examining job complexity, problem solving, interdependence and social support. Journal of Business and Psychology, 34(1), 55-69. doi.org/10.1007/s10869-018-9530-4

Halbesleben, J. R. B. (2010). A meta-analysis of work engagement: Relationships with burnout, demands, resources, and consequences. In A. B. Bakker, \& M. P. Leiter (Eds.). Work engagement: A handbook of essential theory and research (pp. 102-117). New York, NY: Psychology Press.

Humphrey, S. E., Nahrgang, J. D., \& Morgeson, F. P. (2007). Integrating motivational, social, and contextual work design features: A meta-analytic summary and theoretical extension of the work design literature. Journal of Applied Psychology, 92(5), 1332-1356. doi.org/10.1037/00219010.92.5.1332

Johns, T. (2012). Employee Engagement. In: S. Taylor, \& C. Woodhams (Eds.). Managing People and Organisations (pp. 83-110). London, UK: Chartered Institute of Personnel and Development.

Kahn, W. A. (1990). Psychological conditions of personal engagement and disengagement at work. Academy of Management Journal, 33(4), 692-724. doi.org/10.2307/256287

Kossek, E. E., Lautsch, B. A., \& Eaton, S. C. (2009). "Good teleworking": Under what conditions does teleworking enhance employees' well-being? In Y. Amichai-Hamburger (Ed.). Technology and Psychological Well-being (pp. 148-173). Cambridge, UK: Cambridge University Press.
Kwon, K., \& Kim, T. (2020). An integrative literature review of employee engagement and innovative behavior: Revisiting the JD-R model. Human Resource Management Review, 30(2), 1-18. doi.org/10.1016/j.hrmr.2019.100704

Liu, D., Chen, X.-P., \& Yao, X. (2011). From autonomy to creativity: A multilevel investigation of the mediating role of harmonious passion. Journal of Applied Psychology, 96(2), 294-309. doi.org/10.1037/a0021294

Lu, J. G., Brockner, J., Vardi, Y., \& Weitz, E. (2017). The dark side of experiencing job autonomy: Unethical behavior. Journal of Experimental Social Psychology, 73, 222-234. doi.org/10.1016/j.jesp.2017.05.007

Macey, W. H., Schneider, B., Barbera, K. M., \& Young, S. A. (2009). Talent Management Essentials. Employee Engagement: Tools for Analysis, Practice, and Competitive Advantage. Hoboken, NJ: Wiley-Blackwell.

Madanagopal, D., \& Thenmozhi, S. (2015). Relationship between job autonomy and job satisfaction among male employees in the ITeS sector from Chennai city. Annamalai International Journal of Business Studies \& Research, 73-78.

Manzo, L. K. C., \& Minello, A. (2020). Mothers, childcare duties, and remote working under COVID-19 lockdown in Italy: Cultivating communities of care. Dialogues in Human Geography, 10(2), 120-123. doi.org/10.1177/2043820620934268

May, D. R., Gilson, R. L., \& Harter, L. M. (2004). The psychological conditions of meaningfulness, safety and availability and the engagement of the human spirit at work. Journal of Occupational and Organizational Psychology, 77(1), 11-37. doi.org/10.1348/096317904322915892

McClelland, G. P., Leach, D. J., Clegg, C. W., \& McGowan, I. (2014). Collaborative crafting in call centre teams. Journal of Occupational and Organizational Psychology, 87(3), 464-486. doi:10.1111/joop.12058

Morgeson, F. P., \& Humphrey, S. E. (2006). The work design questionnaire (WDQ): Developing and validating a comprehensive measure for assessing job design and the nature of work. Journal of Applied Psychology, 91(6), 13211339. doi.org/10.1037/0021-9010.91.6.1321

Nikolić, J. (2018). Biases in the decision-making process and possibilities of overcoming them. Economic Horizons, 20(1), 43-57. doi:10.5937/ekonhor1801045N

Nunnally, J. C. (1978). Psychometric Theory. 2nd Edition, New York, NY: McGraw-Hill. 
Pattnaik, L., \& Jena, L. K. (2020). Mindfulness, remote engagement and employee morale: Conceptual analysis to address the "new normal". International Journal of Organizational Analysis, 29(4), 873-890. oi.org/10.1108/IJOA06-2020-2267

Radošević, V., Jelić, D., Matanović, J. i Popov, B. (2018). Zahtevi posla i resursi na radu kao prediktori izgaranja na radu i radne angažovanosti: Glavnii interaktivni efekti. Primenjena psihologija, 11(1), 105-125. doi:10.19090/pp.2018.1.105-125

Ryan, R. M., \& Deci, E. L. (2000). Self-determination theory and the facilitation of intrinsic motivation, social development, and well-being. American Psychologist, 55(1), 68-78. doi.org/10.1037/0003-066X.55.1.68

Saks, A. M. (2006). Antecedents and consequences of employee engagement. Journal of Managerial Psychology, 21(7), 600-619. doi.org/10.1108/02683940610690169

Saks, A. M., \& Gruman, J. A. (2014). What do we really know about employee engagement? Human Resource Development Quarterly, 25(2), 155-182. doi.org/10.1002/hrdq.21187

Salanova, M., Agut, S., \& Peiró, J. M. (2005). Linking organizational resources and work engagement to employee performance and customer loyalty: The mediation of service climate. Journal of Applied Psychology, 90(6), 1217-1227. doi.org/10.1037/0021-9010.90.6.1217

Savovic, S., Zlatanovic, D., \& Nikolic, J. (2021). Technology acquisitions as a supporting tool for improving companies' innovative potential. Economic Horizons, 23(1), 3-17. doi:10.5937/ekonhor2101003S

Schaufeli, W. B., \& Bakker, A. B. (2003). Test manual for the Utrecht Work Engagement Scale. Unpublished manuscript, Utrecht University, The Netherlands. Retrieved May 15, 2021, from http://www.schaufeli.com

Schaufeli, W. B., \& Bakker, A. B. (2010). Defining and measuring work engagement: Bringing clarity to the concept. In A. B. Bakker, \& M. P. Leiter (Eds.). Work Engagement: A Handbook of Essential Theory and Research (pp. 10-24). New York, NY: Hove and New York, Psychology Press, Taylor \& Francis Group.

Shantz, A., Alfes, K., Truss, C., \& Soane, E. (2013). The role of employee engagement in the relationship between job design and task performance, citizenship and deviant behaviours. The International Journal of Human Resource Management, 24(13), 2608-2627. doi.org/10.1080/09585192.20 12.744334
Shuck, B., Ghosh, R., Zigarmi, D., \& Nimon, K. (2012). The jingle jangle of employee engagement: Further exploration of the emerging construct and implications for workplace learning and performance. Human Resource Development Review, 12(1), 11-35. doi:10.1177/1534484312463921

Simić, M., Slavković, M., \& Ognjanović, J. (2020). Information literacy competencies in digital age: Evidence from smalland-medium-sized enterprises. In V. Domanović, \& D. Zlatanović (Eds.). Proceedings of the 6 th International Scientific Conference on Contemporary Issues in Economics, Business and Management (EBM 2020) (pp. 105-114). Kragujevac, RS: Faculty of Economics University of Kragujevac, The Republic of Serbia.

Sinha, K. K., \& Van de Ven, A. H. (2005). Designing work within and between organizations. Organization Science, 16(4), 389-408. doi.org/10.1287/orsc.1050.0130

Spiegelaere, S., Van Gyes, G., \& Van Hootegem, G. (2016). Not all autonomy is the same. Different dimensions of job autonomy and their relation to work engagement \& Innovative work behavior. Human Factors and Ergonomics in Manufacturing, 26(4), 515-527. doi.org/10.1002/hfm.20666

Stojanovic-Aleksic, V. (2016). Followers in the organizational leadership process: From attribution to shared leadership. Economic Horizons, 18(2), 135-148. doi:10.5937/ ekonhor1602139S

Tallon, P. P., \& Pinsonneault, A. (2011). Competing perspectives on the link between strategic information technology alignment and organizational agility: Insights from a mediation model. MIS Quarterly, 35(2), 463-486. doi.org/10.2307/23044052

Teece, D., Peteraf, M., \& Leih, S. (2016). Dynamic capabilities and organizational agility: Risk, uncertainty, and strategy in the innovation economy. California Management Review, 58(4), 13-35. doi.org/10.1525/cmr.2016.58.4.13

Thomson, P. (2008). The business benefits of flexible working. Strategic HRReview, 7(2),17-22. doi:10.1108/14754390810853129

Tims, M., \& Bakker, A. B. (2014). Job design and employee engagement. In C. Truss, K. Alfes, R. Delbridge, A. Shantz, \& A. Soane (Eds.). Employee Engagement in Theory and Practice (pp. 131-148) London \& New York, UK \& NY: Routledge, Taylor \& Francis Group 
Wollard, K. K., \& Shuck, B. (2011). Antecedents to employee engagement: A structured review of the literature. Advances in Developing Human Resources, 13(4), 429-446. doi.org/10.1177/1523422311431220

Wrzesniewski, A., \& Dutton, J. (2001). Crafting a job: Revisioning employees as active crafters of their work. Academy of Management Review, 26(2), 179-201. doi.org/10.5465/amr.2001.4378011
Youssef-Morgan, C. M., \& Bockorny, K. M. (2014). Engagement in the context of positive psychology. In C. Truss, R. Delbridge, K. Alfes, A. Shantz, \& E. Soane (Eds.). Employee Engagement in Theory and Practice (pp. 36-56). London \& New York, UK \& NY: Routledge, Taylor \& Francis Group.

Zhang, W., Jex, S. M., Peng, Y., \& Wang, D. (2017). Exploring the effects of job autonomy on engagement and creativity: The moderating role of performance pressure and learning goal orientation. Journal of Business and Psychology, 32(3), 235-251. doi.org/10.1007/s10869-016-9453-x

Primljeno 14. jula 2021, nakon revizije, prihvaćeno za publikovanje 25. novembra 2021. Elektronska verzija objavljena 6. decembra 2021.

Aleksandra Bošković je asistent na Ekonomskom fakultetu Univerziteta u Kragujevcu. Trenutno je doktorand sa prijavljenim doktoratom na istom fakultetu. Nastavu drži na nastavnim predmetima: Organizacija preduzeća, Društvena odgovornost preduzeća i Liderstvo. Oblasti njenog naučno-istraživačkog interesovanja su: organizacioni dizajn, organizaciono ponašanje, angažovanost zaposlenih, društvena odgovornost preduzeća. 


\title{
EMPLOYEE AUTONOMY AND ENGAGEMENT IN THE DIGITAL AGE: THE MODERATING ROLE OF REMOTE WORKING
}

\author{
Aleksandra Boskovic \\ Faculty of Economics, University of Kragujevac, Kragujevac, the Republic of Serbia
}

In the digitalization era, traditional organizational success factors have been called into question, so it is necessary to reconsider the established work patterns and find new ways to create sustainable value. Given the fact that, as bearers of knowledge, people are the key drivers of value, it is important to explore possible ways to improve their potential. The research study carried out in this paper is aimed showing that autonomy contributes to the development of employee engagement in the digital environment, especially so in remote working conditions. In that sense, the concept of employee engagement was explained, as a state of high vigor, dedication and absorption. Possible ways to improve engagement through increasing autonomy are pointed out as well. The empirical research has confirmed that autonomy has a positive effect on vigor and dedication as the engagement dimensions. The impact autonomy exerts on vigor is stronger in the employees working remotely in comparison with those who do not work remotely.

Keywords: autonomy, job design, employee engagement, remote working, digital environment, organizational design

JEL Classification: M20, M12, J28 